\title{
Allene Functionalized Azobenzene Linker Enables Rapid and Light-Responsive Peptide Macrocyclization
}

Mohammad R. Jafari, Jenner Lakusta, Rylan J. Lundgren, Ratmir Derda*

Department of Chemistry and Alberta Glycomics Centre, University of Alberta, Edmonton, Alberta, T6G 2G2, Canada

Corresponding author: ratmir.derda@ualberta.ca

\section{Table of contents}

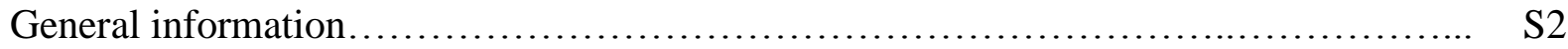

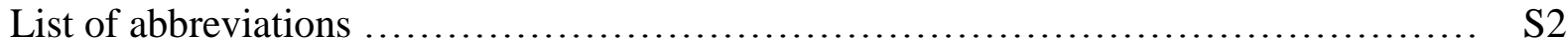

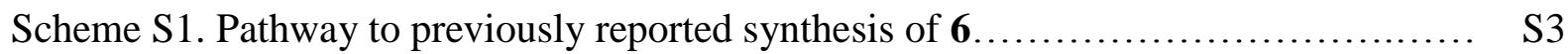

Measuring the kinetics of reaction of glutathione (GSH) with BSBDA (14) ............. S4

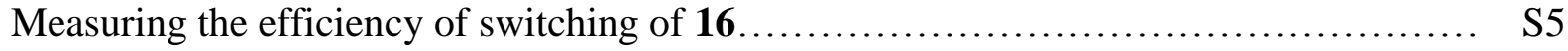

Measuring the biotinylation of the phage with BIA .................................. S5

Measuring the reaction of the phage with BSBDA................................ S5

Supplementary Figure S1. Kinetics of reaction of BSBDA with GSH................ S6

Supplementary Figure S2. Cyclization of $\mathbf{P 3 6}$ with BSBDA in the presence of BSBCA... S7

Supplementary Figure S3. Kinetic of thermal relaxation of 16..................... S8

Synthesis of 2-(dodecanoylamino)-5-nitrobenzenesulfonic acid (2).................. S8

Synthesis of 5-amino-2-(dodecanoylamino)benzenesulfonic acid $(\mathbf{3}) \ldots \ldots \ldots \ldots \ldots \ldots \ldots$ S9

Synthesis of Sodium 2-[(4-methoxybenzyl)amino]-benzenesulfonate (4) ............. S10

Synthesis of 3,3'-bis(sulfonato)-(4-methoxybenzyl)amido-(4'-dodecanoylamido)-

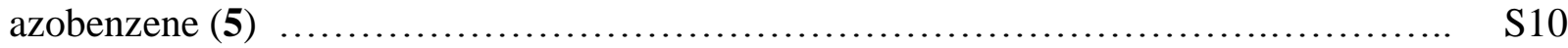

Synthesis of 3,3'-bis(sulfonato)-4,4'-bis(amino)azobenzene trifluoroacetate (6) .......... S11

Synthesis of 2-(acetylamino)benzenesulfonic acid (7).............................. S12

Synthesis of 2-(1,3-dihydro-2H-isoindol-2-yl)benzenesulfonic acid (9) ............... S12

Synthesis of 3,3'-bis(sulfonato)-4,4'-bis(bromoacetamido)azobenzene (11).............. S13

Synthesis of 3,3'-bis(sulfonato)-4,4'-bis(azidoacetamido)azobenzene (12) .............. S13

Synthesis of 3,3'-bis(sulfonato)-4,4'-bis(prop-2-ynoylamido)azobenzene (13)............ S14

Synthesis of 3,3'-bis(sulfonato)-4,4'-bis(buta-2,3-dienoylamido)azobenzene (14) .......... S15

Synthesis of cyclized peptide ACGFERERTCG (16) ............................... S15

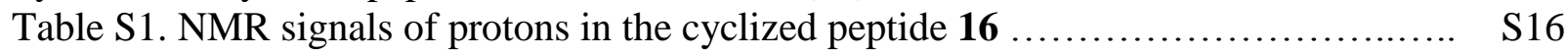

Scheme S2. Structure of $\mathbf{1 6}$ with explicit hydrogens.................................. S17

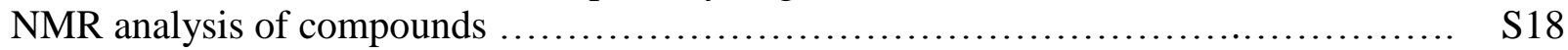

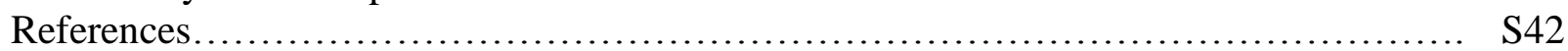




\section{List of abbreviations}

$\begin{array}{ll}\text { DMF } & \text { dimethylformamide } \\ \text { THF } & \text { tetrahydrofuran } \\ \text { DCM } & \text { dichloromethane } \\ \text { TFA } & \text { trifluoroacetic acid } \\ \text { DIPEA } & N, N \text {-diisopropylethylamine } \\ \text { r.t. } & \text { room temperature } \\ \text { MOPS } & \text { 3-(N-morpholino)propanesulfonic acid, } \\ \text { BIA } & \text { Biotin-PEG } 2 \text {-iodoacetamide } \\ \text { TCEP } & \text { tris(2-carboxyethyl)phosphine }\end{array}$

\section{General Information:}

Chemical reagents and solvents were purchased from Sigma-Aldrich or TIC chemicals unless otherwise noted. 3-butynoic acid and ${ }^{1} 2$-azidoacetic acid ${ }^{2}$ were synthesized according a previously published protocols and their spectroscopic characteristics matched to the previously reported. 3-butyne-1-ol was purchased from AKScientific. BSBCA (10) was synthesized from 3,3'bis(sulfonato)-4,4'-bis(chloroacetamido)azobenzene in $89 \%$ yield according to previous protocols and the spectroscopy characteristics matched to the previously reported compound. ${ }^{3}$ Peptide sequence ACGFERERTCG was purchased from Lifetein and was purified by HPLC before use. Proton $\left({ }^{1} \mathrm{H}-\mathrm{NMR}\right)$ and Carbon $\left({ }^{13} \mathrm{C}-\mathrm{NMR}\right)$ nuclear magnetic resonance spectra were recorded on an Agilent/Varian VNMRS two channel $500 \mathrm{MHz}$ or Agilent/Varian Inova two-channel 400 MHz spectrometer. The chemical shifts are given in part per million (ppm). The solvent peak was used as a reference. The following abbreviations were used: s, singlet; $d$, doublet; t, triplet; m, multiplet; b, broad; d, doublet of doublet of doublets. High resolution ESI mass spectra (HRMS) were recorded by Agilent Technologies 6220 oaTOF. Preparative HPLC was conducted using Waters 1525 Binary pump equipped with a Waters Symmetryprep 19×50 mm C18 Columns and Waters 2489 UV detector. We used following method for HPLC purification unles otherwise noted: A gradient of solvent A $(0.1 \%$ TFA in MQ water) and solvent B $(0.1 \%$ TFA in $\mathrm{MeCN})$ was run at a flow rate of $8 \mathrm{~mL} / \mathrm{min}(0-2 \mathrm{~min} 5 \% \mathrm{~B} ; 2-18 \mathrm{~min} 5 \% \rightarrow 50 \% \mathrm{~B} ; 18-21 \mathrm{~min}$ $50 \% \rightarrow 100 \% \mathrm{~B} ; 21-24100 \% \rightarrow 2 \% \mathrm{~B}$ ). LCMS data was obtained on Agilent Technologies 6130 
LCMS. A gradient of solvent A (MQ water) and solvent B $\left(\mathrm{MeCN} / \mathrm{H}_{2} \mathrm{O} 95 / 5\right)$ was run at a flow rate of $0.5 \mathrm{~mL} / \mathrm{min}(0-0.4 \mathrm{~min} 5 \% \mathrm{~B}$; $0.4-5 \mathrm{~min} 5 \% \rightarrow 60 \% \mathrm{~B} ; 5-5.5 \mathrm{~min} 60 \% \rightarrow 100 \% \mathrm{~B}$; 5.50 $7.50100 \% \mathrm{~B}, 7.50-11 \mathrm{~min} 100 \% \rightarrow 5 \% \mathrm{~B})$.
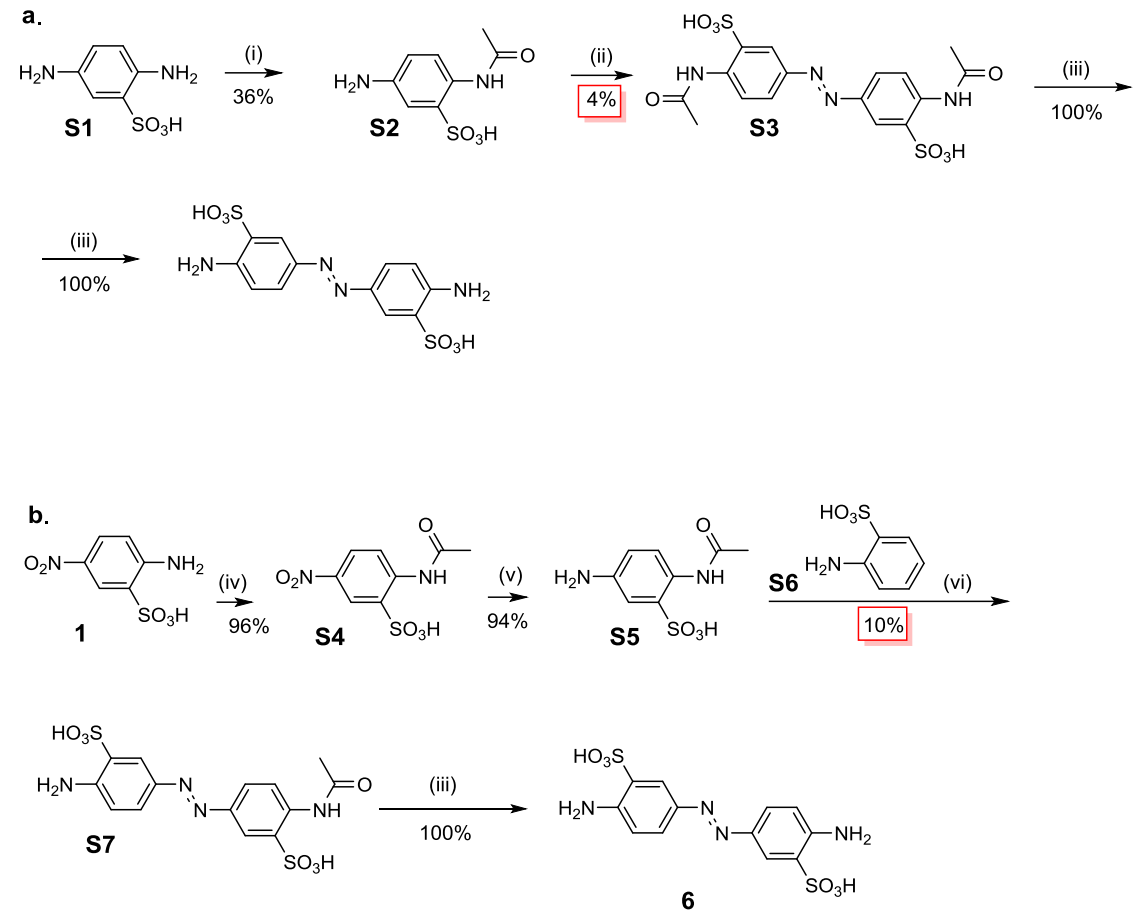

Scheme S1. a) The original synthetic route to 6 by Zhang et al. ${ }^{4}$ (i) Acetic acid, acetic anhydride, $2 \mathrm{~h}$, reflux. (ii) $\mathrm{NaClO}, \mathrm{pH} 8.5,3$ days, $4{ }^{\circ} \mathrm{C}$, dark. (iii) $2 \mathrm{M} \mathrm{HCl}, 2 \mathrm{~h}$ reflux. b) Synthesis of 6 through diazo coupling by Jafari et al. ${ }^{5}$ (iv) acetic anhydride, acetic acid, 2 h, reflux. (v) $\mathrm{H}_{2}$, $\mathrm{Pd} / \mathrm{C}, \mathrm{MeOH}, 3 \mathrm{~h}$. (vi) 1. $1 \mathrm{M} \mathrm{HCl} / \mathrm{MeOH}=1 / 1, \mathrm{NaNO}_{2}, 0{ }^{\circ} \mathrm{C}, 1$ h. 2 . Sodium 2aminobenzenesulfonate (aq), $\mathrm{pH} 8.5$, overnight. Highlighted steps exhibit low yields and/or difficulties in purification of the product.

\section{Measuring the kinetics of reaction of glutathione (GSH) with BSBDA}

To $150 \mu \mathrm{L}$ of $0.1 \%$ TFA in $\mathrm{H}_{2} \mathrm{O}$ solution, we added $2 \mu \mathrm{L}$ of a fresh solution of $16 \mathrm{mM}$ GSH in water, followed by $10 \mu \mathrm{L}$ of $100 \mu \mathrm{M}$ solution of BSBDA in $\mathrm{H}_{2} \mathrm{O}$. The reaction was triggered by addition of $25 \mu \mathrm{L}$ of $500 \mathrm{mM}$ MOPS buffer ( $\mathrm{pH} 8.5)$ to adjust the $\mathrm{pH}$ of the mixture to 8.0 and the reaction was mixed by pipetting. We added $30 \mu \mathrm{L}$ of reaction mixture to $5 \mu \mathrm{L}$ of glacial acetic acid to stop the reaction at $0.5,1,2,4,10$ and $20 \mathrm{~min}$. 


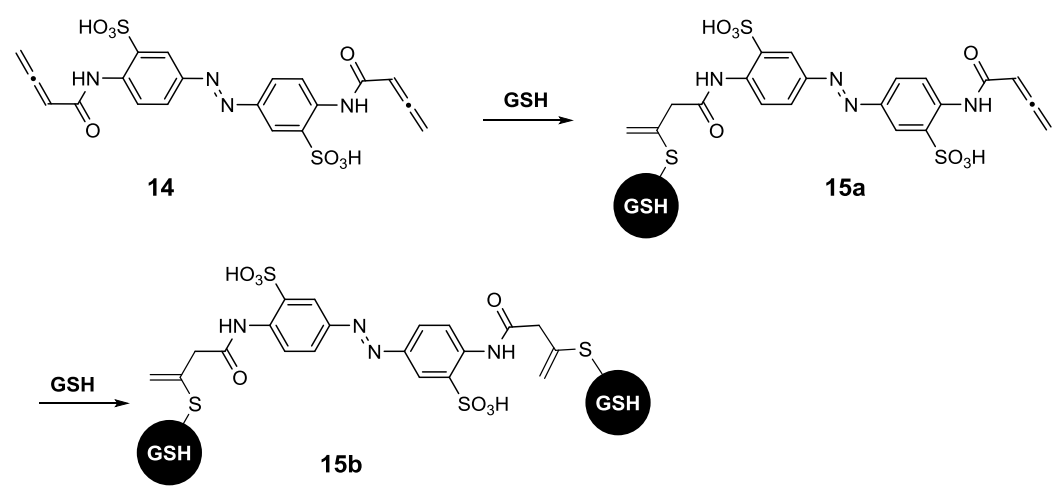

The data was processed using MATLAB to fit the reading to consecutive pseudo first order kinetic process:

$$
14 \stackrel{k 1}{\rightarrow} 15 a \stackrel{k 2}{\rightarrow} 15 b
$$

$\mathrm{A}_{\mathrm{t}}=A_{0} e^{k_{1} t}$

$\mathrm{B}_{\mathrm{t}}=\frac{k_{1} A_{0}}{k_{2}-k_{1}}\left(e^{-k_{1} t}-e^{-k_{2} t}\right)$

$\mathrm{C}_{\mathrm{t}}=\mathrm{A}_{0}\left[1+\frac{1}{k_{1}-k_{2}}\left(k_{2} e^{-k_{1} t}-k_{1} e^{-k_{2} t}\right)\right]$

where $A_{t}, B_{t}$ and $C_{t}$ are area under the curve (AUC) for 14, 15a and 15b, respectively, at time t. $\mathrm{A}_{0}$ is initial AUC and the $\mathrm{k}_{1}$ and $\mathrm{k}_{2}$ are the rate constants of the first and second reaction. (Figure S1)

\section{Measuring the efficiency of switching of 16}

We prepared a $0.2 \mathrm{mM}$ solution of $\mathbf{1 6}$ in $50 \mathrm{mM} \mathrm{NH}_{4} \mathrm{OAc}(\mathrm{pH}$ 7.2) in water. We transferred 100 $\mu \mathrm{L}$ of this solution to a $300 \mu \mathrm{L}$ glass vial insert and irradiated the solution with $365 \mathrm{~nm}$ LED for $2 \mathrm{~min}$. A $10 \mu \mathrm{L}$ of the solution was then injected to LCMS system to separate the cis and trans isomers on C8 column at 15 minutes intervals. The absorption of each isomer at $322 \mathrm{~nm}$ (isosbestic point) showed the amount of each isomer in the solution. The data was fitted into first order kinetics: $A_{t}=A_{0}+A\left(1-e^{-k C t}\right)$ using MatLab software. The $A_{0}$ was then interpolated to give the amount of cis and trans isomer at $\mathrm{t}_{0}$ (Figure $\mathrm{S} 2$ ). 


\section{Measuring the biotinylation of the phage with BIA}

To $96.5 \mu \mathrm{L}$ of a solution of $10^{11} \mathrm{pfu} / \mathrm{mL}$ of phage (sequence ACPARSPLEC/WT = 5/1) in 50 mM Tris buffer ( $\mathrm{pH} 8.5$ ), we added $2.5 \mu \mathrm{L}$ of $20 \mathrm{mM}$ TCEP followed by $1 \mu \mathrm{L}$ of $100 \mathrm{mM}$ BIA. We incubated this reaction for $30 \mathrm{~min}$ at r.t. and then stopped the reaction by diluting it $10^{7}$ times in PBS (i.e., three serial 1:100 dilutions performed by mixing of $10 \mu \mathrm{L}$ of the reaction mixture and $990 \mu \mathrm{L}$ PBS, and one 1:10 dilution). The reaction was split in two aliquots of $\mathrm{A}$ and $\mathrm{B}$. We added aliquot A to $10 \mu \mathrm{L}$ of pre-washed streptavidin coated magnetic beads (Promega) and agitated the mixture for $10 \mathrm{~min}$ at $1000 \mathrm{rpm}$ using IKA MS 3 digital orbital shaker. Then we captured the beads on a magnetic stand and titered the supernatant of $\mathrm{A}$ and the aliquot $\mathrm{B}$. The amount of biotinylation was calculated as:

$\%$ Biotinylated phage $=[($ titer of $\mathrm{B}-$ titer of $\mathrm{A}) /$ titer of $\mathrm{B}] \times 100 \%$

\section{Measuring the reaction of the phage with BSBDA}

To $96.5 \mu \mathrm{L}$ of a solution of $10^{11} \mathrm{pfu} / \mathrm{mL}$ of phage (sequence ACPARSPLEC/WT $=5 / 1$ ) in 50 $\mathrm{mM}$ Tris buffer ( $\mathrm{pH} 8.5$ ), we added $2.5 \mu \mathrm{L}$ of $20 \mathrm{mM}$ TCEP followed by $2.5 \mu \mathrm{L}$ of $20 \mathrm{mM}$ BSBDA. We incubated this reaction for $30 \mathrm{~min}$ at r.t. and then added $1 \mu \mathrm{L}$ of a $100 \mathrm{mM}$ solution

of BIA in DMF. We stopped the reaction by diluting it $10^{7}$ times in PBS. The reaction was split in two aliquots of $\mathrm{A}$ and $\mathrm{B}$. We added aliquot $\mathrm{A}$ to $10 \mu \mathrm{L}$ of pre-washed streptavidin coated magnetic beads (Promega) and agitated the mixture for $10 \mathrm{~min}$ at $1000 \mathrm{rpm}$ using IKA MS 3 digital orbital shaker. Then we captured the beads on a magnetic stand and titered the supernatant of $\mathrm{A}$ and the aliquot $\mathrm{B}$. The amount of biotinylation was calculated as:

$\%$ Biotinylated phage $=[($ titer of $\mathrm{B}-$ titer of $\mathrm{A}) /$ titer of $\mathrm{B}] \times 100 \%$

Reacted Phage $=100 \%$ - \%biotinylated phage 
A.

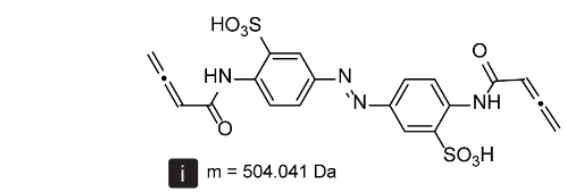

$\downarrow$ Glutathion (GSH)
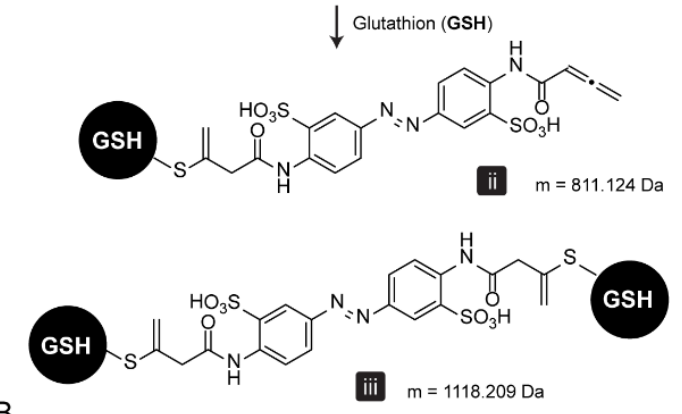

$B$.
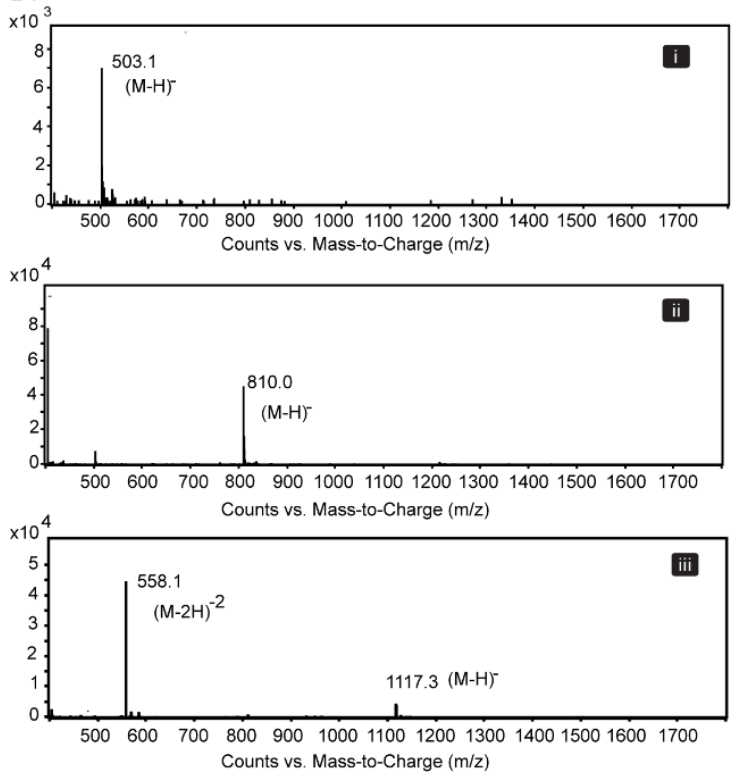

C.

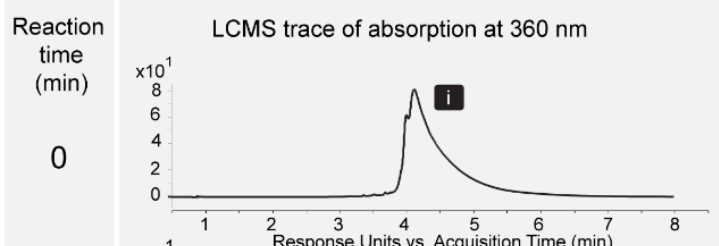

0.5

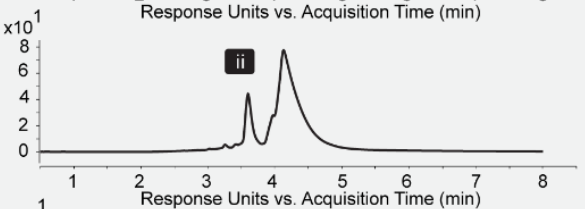

1

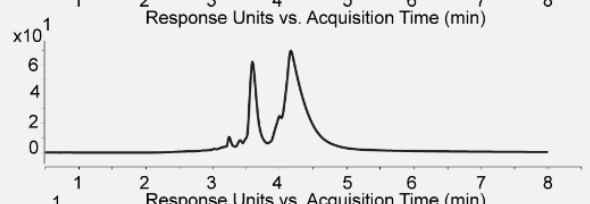

2

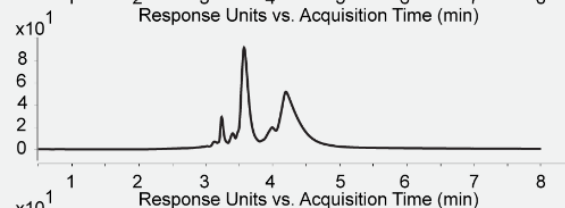

4

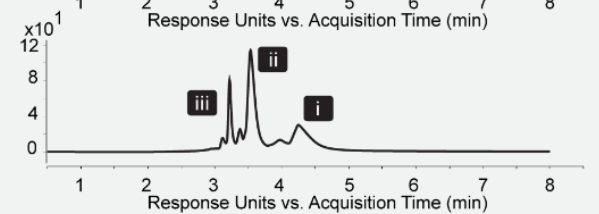

10

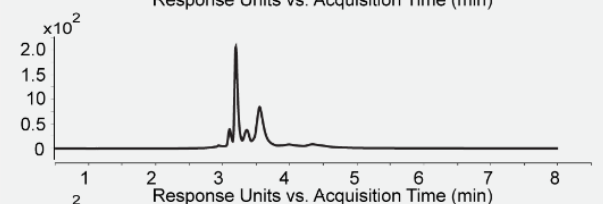

20

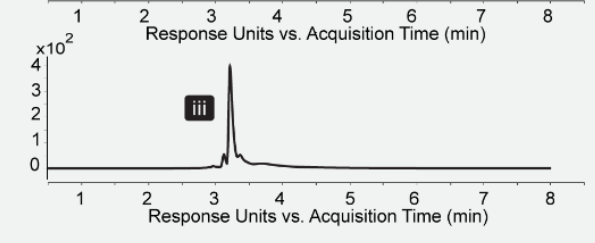

Figure S1. Kinetics of reaction of BSBDA with GSH. A) Reaction of BSBDA (14) with glutathione can result in formation of mono- and di-substituted product. B) Mass spectra of BSBDA (i), mono-substituted product (ii) and di-substituted product (iii). C) LCMS trace of the reaction of BSBDA with GSH shows the consumption of BSBDA and formation of di-substituted product in $20 \mathrm{~min}$. 
A.

A.

B.
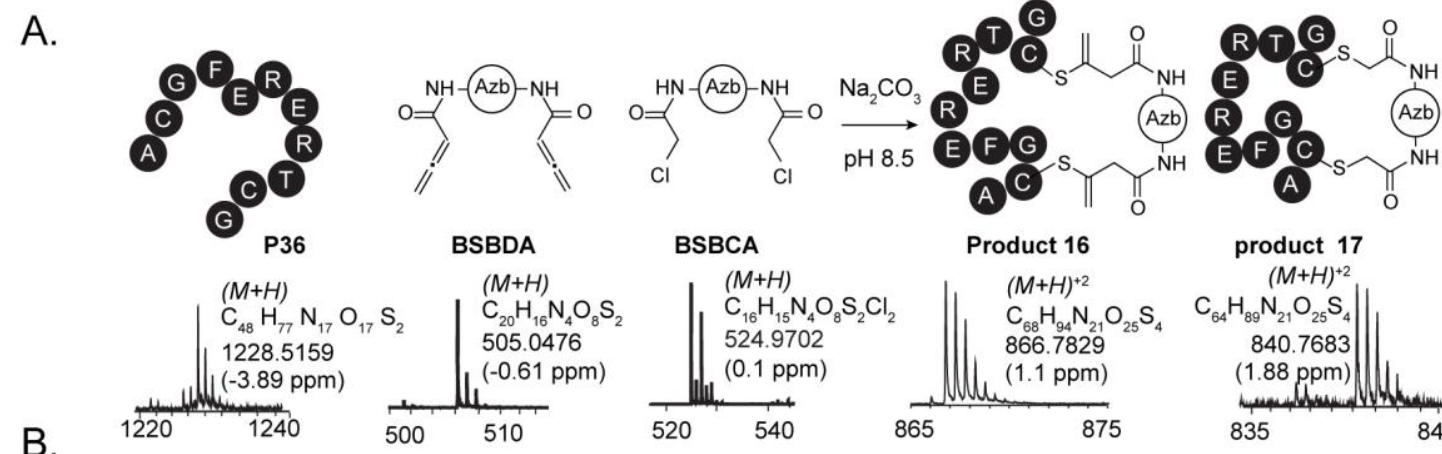

Product 16

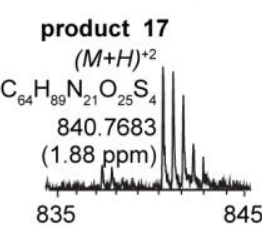

Reaction

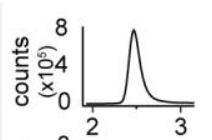

0
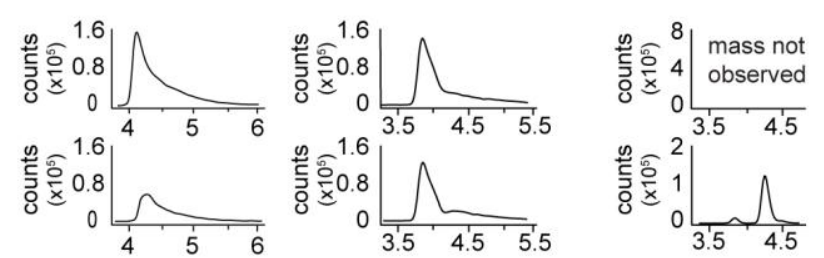

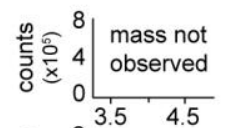

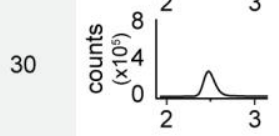

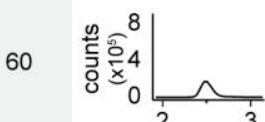
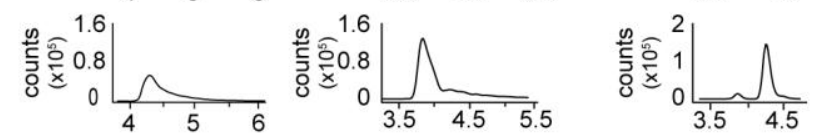

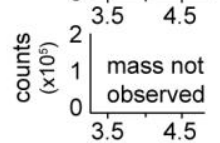
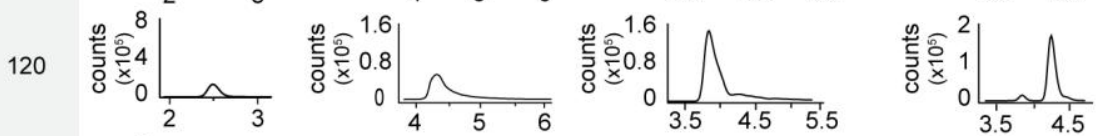

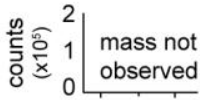

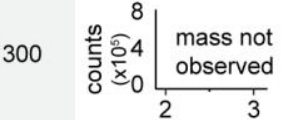
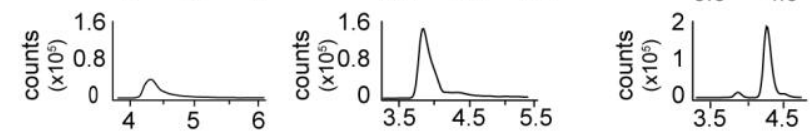

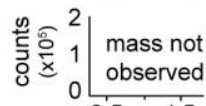

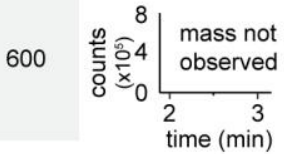
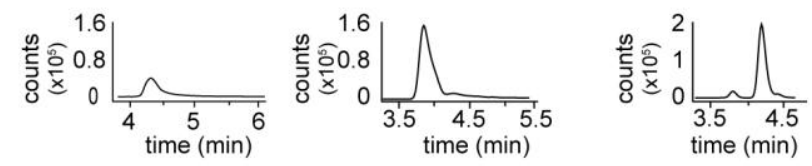

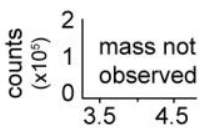

C.
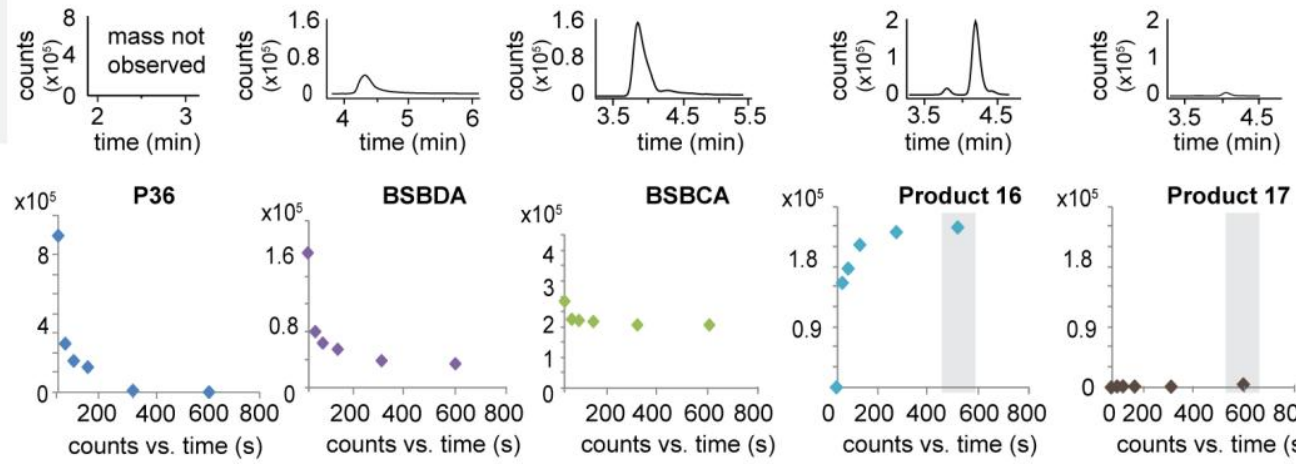

Product $16 /$ Product $17=98.60 / 1.40$

Figure S2. A) Cyclization of P36 $(100 \mu \mathrm{M})$ with BSBDA $(160 \mu \mathrm{M})$ in the presence of BSBCA $(160 \mu \mathrm{M})$. Over $85 \%$ of the product 16 was formed in 2 min. All of the peptide was consumed in $5 \mathrm{~min}$. The ratio of product $\mathbf{1 6}$ to product 17 was 98.60/1.40 after $10 \mathrm{~min}$. B) To monitor this reaction, at the indicated time points $(0,30,600,120,300$ and $600 \mathrm{~s})$, we sampled $15 \mu \mathrm{L}$ of the reaction, quenched it with $5 \mu \mathrm{L}$ of acetic acid and injected $12 \mu \mathrm{L}$ of this mixture onto Agilent Technologies nano-LC high-resolution-MS equipped with 6220 oaTOF detector. C) In each spectrum, we identified desired high-resolution MS peak (A), extracted and integrated the total ion count (EIC) elution profile for this fragment 


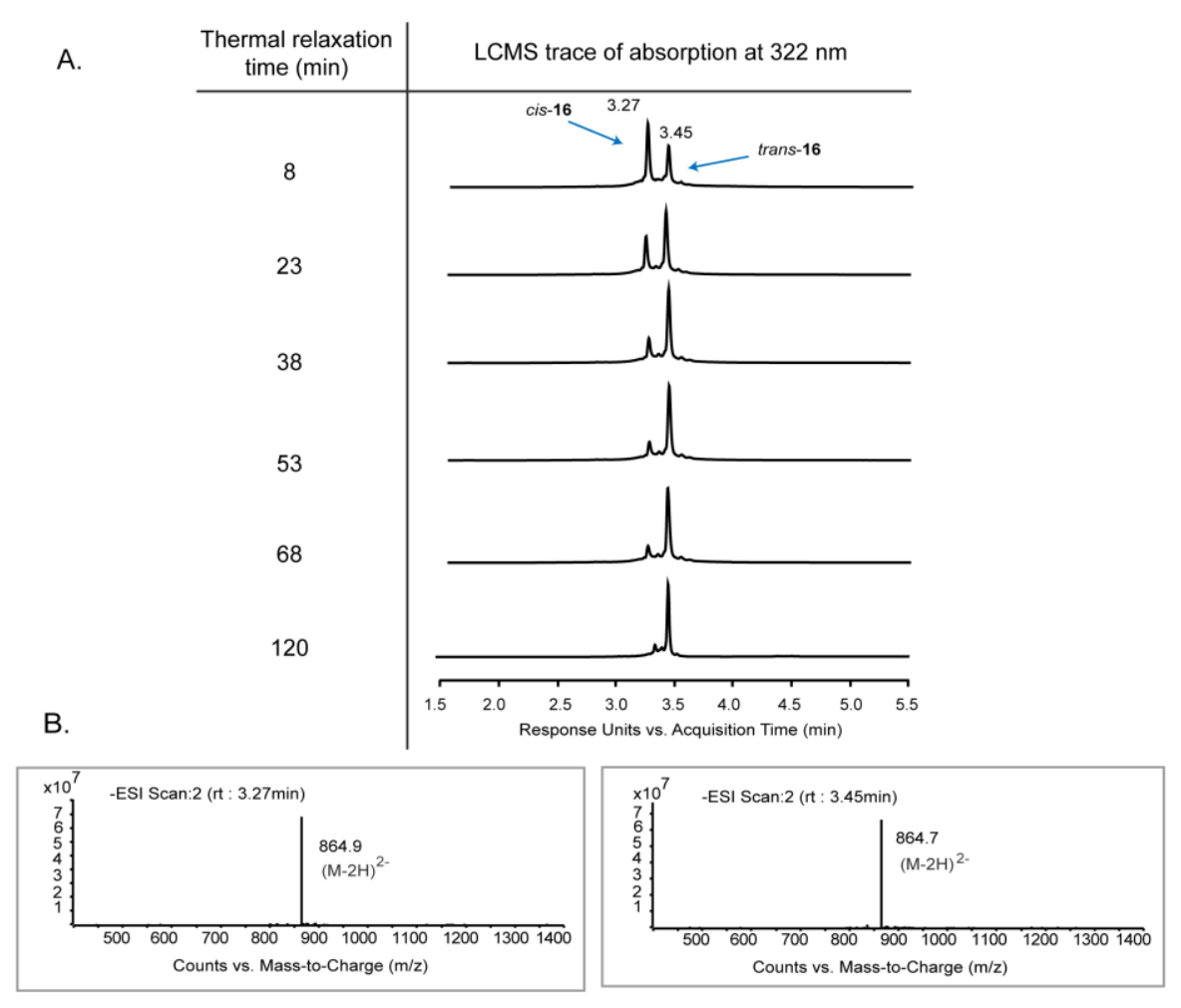

Figure S3. Kinetic of thermal relaxation of 16. A) Cis- and trans-16 can be isolated on C8 column using LCMS instrument after thermal relaxation. Changes in absorption of $\mathbf{1 6}$ at $322 \mathrm{~nm}$ (isosbestic point) 8, 23, 38, 53, 68 and 120 min of thermal relaxation after irradiation with 365 nm LED. B) Mass spectra of cis and trans-16.

Synthesis of 2-(dodecanoylamino)-5-nitrobenzenesulfonic acid (2)<smiles>CCCCCCCCCCCC(=O)Nc1ccc([N+](=O)[O-])cc1O</smiles>

To a solution of sodium 2-amino-5-nitrobenzenesulfonate (1.2 g, $5 \mathrm{mmol}$, TCI Chemicals) in icecold dry DMF, we added lauroyl chloride $(1.1 \mathrm{~mL}, 5.5 \mathrm{mmol}$, TCI Chemicals) drop wise. The reaction was warmed up to room temperature and then stirred at $110{ }^{\circ} \mathrm{C}$ for $4 \mathrm{~h}$. The reaction was cooled down to r.t., the solvent was evaporated under vacuum and the resulting crude mixture was re-dissolved in $50 \mathrm{~mL}$ of DCM. The DCM solution was washed with $25 \mathrm{~mL}$ of $2 \mathrm{M} \mathrm{HCl}$, 
organic layer was separated and the DCM was removed by rotary evaporator. The resulting viscose liquid was purified by column chromatography and the product was eluted using $\mathrm{DCM} / \mathrm{MeOH}=8 / 2$. The solvent was removed by rotary evaporator and the resulting pale yellow oil was incubated at room temperature under vacuum for $24 \mathrm{~h}$ to yield compound 9 as pale yellow solid (1.89 g, 92\%). ${ }^{1}$ H-NMR (399.8 MHz, DMSO) $\delta 10.66$ (br, $\left.1 \mathrm{H}, \mathrm{NH}\right), 8.56$ (d, J=9.2 $\mathrm{Hz}, 2 \mathrm{H}), 8.43(\mathrm{~d}, J=2.8 \mathrm{~Hz}, 2 \mathrm{H}), 8.19(\mathrm{~d}, J=2.8 \mathrm{~Hz}, J=9.2 \mathrm{~Hz}, 2 \mathrm{H}), 2.34$ (t, $J=7.6 \mathrm{~Hz}, 2$ H), $1.59(\mathrm{~m}, 2 \mathrm{H}), 1.2(\mathrm{~m}, 16 \mathrm{H}), 0.81(\mathrm{t}, J=6.8 \mathrm{~Hz}, 3 \mathrm{H}) \mathrm{ppm} .{ }^{13} \mathbf{C}-\mathbf{N M R}(100.5 \mathrm{MHz}, \mathrm{DMSO})$ $\delta 171.8,141.4,141.4,135.6,125.9,122.9,119.5,38.1,31.7,29.5,29.4,29.2,28.9,25.1,225.5$, 14.3 ppm. HRMS-ESI $(m / z)$ : $(\mathrm{M}-\mathrm{H})^{-}$calc. for: $\mathrm{C}_{18} \mathrm{H}_{27} \mathrm{~N}_{2} \mathrm{O}_{6} \mathrm{~S}: 399.1595$, observed: 399.1594, $0.29 \mathrm{ppm}$.

Synthesis of 5-amino-2-(dodecanoylamino)benzenesulfonic acid (3)

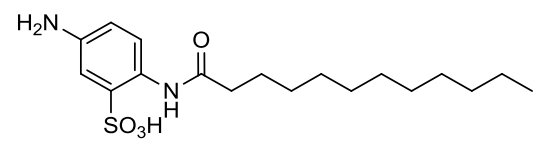

To a solution of $2(1.2 \mathrm{~g}, 3 \mathrm{mmol})$ in $100 \mathrm{~mL}$ of $\mathrm{MeOH}$, we added $\mathrm{Pd} / \mathrm{C}(100 \mathrm{mg}, 0.1 \mathrm{mmol})$ with vigorous stirring. We put a white septum on the flask and passed hydrogen through a needle for 2 min. Then we attached a balloon on the septum, filled it with hydrogen $(\sim 2 \mathrm{~L})$ and let the reaction mixture to stir for $2 \mathrm{~h}$. After completion of the reaction, we filtered the reaction mixture through celite and removed the solvent by rotary evaporator. The resulting solid was purified on silica by column chromatography and eluted by $\mathrm{DCM} / \mathrm{MeOH}=8 / 2$ to yield 3 as pale yellow solid (1.09 g, 96\%). ${ }^{1}$ H-NMR (399.8 MHz, DMSO) $\delta 10.0$ (s, 1 H), 7.99 (s, J = 8.4 Hz, 2 H), 7.1 $(\mathrm{d}, J=2.4 \mathrm{~Hz}, 2 \mathrm{H}), 6.61(\mathrm{dd}, J=2.4 \mathrm{~Hz}, J=8.4 \mathrm{~Hz}, 2 \mathrm{H}), 2.20(\mathrm{t}, J=7.2 \mathrm{~Hz}, 2 \mathrm{H}), 1.57(\mathrm{t}, J=$ $6.8 \mathrm{~Hz}, 2 \mathrm{H}), 1.27-1.17(\mathrm{~m}, 16 \mathrm{H}), 0.85(\mathrm{t}, J=6.4 \mathrm{~Hz}, 3 \mathrm{H}) \mathrm{ppm} .{ }^{13} \mathrm{C}-\mathbf{N M R}(100.5 \mathrm{MHz}$, DMSO) $\delta 170.0,141.2,136.5,126.8,121.3,116.4,114.3,55.5,46.2,38.2,31.7,29.5,29.4,29.4$, 29.2, 29.2, 29.0, 25.5, 22.5, 14.4, 9.0. HRMS-ESI $(\mathrm{m} / \mathrm{z})$ : $(\mathrm{M}-\mathrm{H})^{-}$calc. for: $\mathrm{C}_{18} \mathrm{H}_{29} \mathrm{~N}_{2} \mathrm{O}_{4} \mathrm{~S}$ : 369.1854, observed: 369.1847; 1.84 ppm. 
Synthesis of sodium 2-[(4-methoxybenzyl)amino]-benzenesulfonate (4)

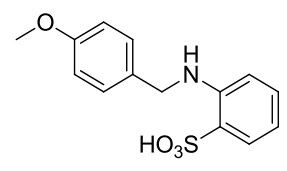

To $3.0 \mathrm{~mL}$ of anisaldehyde (30 mmol, TCI chemicals), we added $1.54 \mathrm{~g}(10 \mathrm{mmol})$ of 2 aminobenzenesulfonic acid. The resulting suspension was stirred overnight at $110{ }^{\circ} \mathrm{C}$ in the presence of activated molecular sieves. We then cooled down the reaction mixture to r.t. and diluted it with $30 \mathrm{~mL}$ DCM. The suspension was vacuum filtered through Whatman grade 1 filter paper and the yellow precipitate was washed 5 times with DCM. We then collected the solid residue and re-suspended it in $50 \mathrm{~mL} \mathrm{MeOH}$. The suspension was stirred on ice for $30 \mathrm{~min}$ and then 370 $\mathrm{mg}(10 \mathrm{mmol})$ of sodium borohydride was added in four portions. We stirred the suspension for $2 \mathrm{~h}$ on ice followed by $6 \mathrm{~h}$ at r.t. After quenching the excess of sodium borohydride with slow addition of ice-cold water to the mixture, we added $\mathrm{HCl}$ until the $\mathrm{pH}$ of the solution reached $\sim 1$ (as determined by universal $\mathrm{pH}$ paper). Cooling the solution on ice resulted in precipitation of white solid flakes, which were collected by vacuum filtration. Drying the solid in vacuo yielded the product 4 as a white solid (1.9 g, $65 \%$ over two steps). ${ }^{1} \mathbf{H}-\mathbf{N M R}(300.0 \mathrm{MHz}, \mathrm{DMSO}) \delta 7.47$ $(\mathrm{dd}, J=2.4 \mathrm{~Hz}, J=10 \mathrm{~Hz}, 1 \mathrm{H}), 7.27(\mathrm{dd}, J=2.8 \mathrm{~Hz}, J=8.8 \mathrm{~Hz}, 2 \mathrm{H}), 7.01(\mathrm{t}, J=8.8 \mathrm{~Hz}, 1 \mathrm{H})$, $6.87(\mathrm{dd}, J=2.8 \mathrm{~Hz}, J=8.8 \mathrm{~Hz}, 2 \mathrm{H}), 6.74(\mathrm{t}, J=7.6 \mathrm{~Hz}, 1 \mathrm{H}), 6.49-6.43(\mathrm{~m}, 2 \mathrm{H}), 4.24(\mathrm{~d}, \mathrm{~J}=$ $7.6 \mathrm{~Hz}, 2 \mathrm{H}), 3.72$ (s, $3 \mathrm{H})$ ppm. ${ }^{13} \mathbf{C}-\mathbf{N M R}(100.5 \mathrm{MHz}, \mathrm{DMSO}) \delta$ 158.6, 145.2, 132.0, 131.2, 130.4, 128.8, 127.6, 114.6, 114.2, 111.0, 55.5, 46.4 ppm. HRMS-ESI $(\mathrm{m} / \mathrm{z})$ : $(\mathrm{M}-\mathrm{H})^{-}{ }^{-}$calc. for: $\mathrm{C}_{14} \mathrm{H}_{14} \mathrm{NO}_{4} \mathrm{~S}=292.0649$, observed: $292.0649 ;-0.5$ ppm.

Synthesis of 3,3'-bis(sulfonato)-(4-methoxybenzyl)amido-(4'-dodecanoylamido)-azobenzene (5)

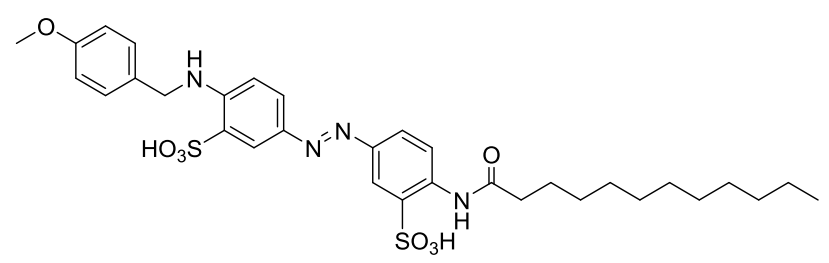

To an ice cold solution of 2-amino-5-nitrobenzenesulfonate (3) $(1.85 \mathrm{~g}, 5 \mathrm{mmol})$ in $2 \mathrm{M} \mathrm{HCl}$ (4 $\mathrm{mL})$ and $\mathrm{MeOH}(50 \mathrm{~mL})$, we added $5 \mathrm{~mL}$ of a solution of $1 \mathrm{M} \mathrm{NaNO}_{2}$ drop-wise. Stirring this solution for $1 \mathrm{~h}$ yielded the diazonium salt of 3 . We dissolved the PMB-2-ABS $(4,1.7 \mathrm{~g}, 6$ 
mmol) in $2 \mathrm{~mL}$ of $2 \mathrm{M}$ aqueous $\mathrm{NaOH}$ solution and diluted this solution by adding $20 \mathrm{~mL}$ of $\mathrm{MeOH}$. This methanolic solution of $\mathbf{4}$ was stirred on ice for $20 \mathrm{~min}$. We then added the diazonium salt suspension to the ice cold solution of $\mathbf{4}$ slowly with vigorous stirring. After stirring for 15 min, we added $100 \mathrm{~mL}$ of ice-cold DCM to the mixture and continued stirring vigorously on ice bath for $1 \mathrm{~h}$. We noticed that adding the DCM was critical possibly because of higher solubility of the fatty acid protected diazonium salt in DCM. A $10 \mathrm{~cm}$ magnetic stir bar and high stirring speed $(2000 \mathrm{rpm})$ were used to ensure proper mixing of the aqueous and organic phase. We then warmed up the reaction mixture to room temperature and increased the $\mathrm{pH}$ to 5.0 by slowly adding saturated solution of $\mathrm{NaHCO}_{3}$ to the reaction. The reaction turned pale orange in $1 \mathrm{~h}$ and deep red after $18 \mathrm{~h}$ of stirring. We transferred the reaction mixture to a separatory funnel, separated the orange-colored organic layer, extracted the aqueous layer twice with $25 \mathrm{~mL}$ of DCM, combined organic layers and then removed the DCM by rotary evaporator. The resulting red crude solid was purified by column chromatography on silica and the product eluted in $\mathrm{DCM} / \mathrm{MeOH}=3 / 1$. Removing of the solvent by a rotary evaporator yielded compound $\mathbf{5}$ as a dark orange solid (1.8 g, 55\%). ${ }^{1}$ H-NMR (399.8 MHz, DMSO) $\delta 10.6(\mathrm{~s}, 1 \mathrm{H}), 8.48(\mathrm{~d}, J=8.4$ $\mathrm{Hz}, 1 \mathrm{H}), 8.12(\mathrm{~d}, J=2.0 \mathrm{~Hz}, 1 \mathrm{H}), 8.08(\mathrm{~d}, J=2.0 \mathrm{~Hz}, 1 \mathrm{H}), 7.78(\mathrm{dd}, J=8.8 \mathrm{~Hz}, J=2.0 \mathrm{~Hz}, 1$ H), $7.72(\mathrm{dd}, J=8.8 \mathrm{~Hz}, J=2.0 \mathrm{~Hz}, 1 \mathrm{H}), 7.31(\mathrm{~d}, J=8.4 \mathrm{~Hz}, 2 \mathrm{H}), 6.92(\mathrm{~d}, J=8.4 \mathrm{~Hz}, 2 \mathrm{H})$, $6.70(\mathrm{~d}, J=8.8 \mathrm{~Hz}, 1 \mathrm{H}), 4.42$ (s, $2 \mathrm{H}), 3.74$ (s, $3 \mathrm{H}), 2.31$ (t, $J=7.6 \mathrm{~Hz}, 2 \mathrm{H}), 1.62$ (t, $J=7.6,2$ H), 1.29-1.14 (m, $16 \mathrm{H}), 0.84$ (t, $J=6.8,3 \mathrm{H}) \mathrm{ppm} .{ }^{13}$ C-NMR (100.5 MHz, DMSO) $\delta 171.2$, 158.8, 147.9, 147.2, 142.0, 136.8, 136.1, 131.5, 1313.1, 128.9, 127.7, 125.4, 121.1, 120.2, 119.3, 114.4, 110.9, 55.5, 46.2, 38.1, 29.5, 29.4, 29.4, 29.3, 29.2, 29.2, 29.0, 25.3, 22.5, 14.4 ppm. HRMS-ESI $(\mathrm{m} / \mathrm{z})$ : $(\mathrm{M}-2 \mathrm{H})^{2-}$ calc. for: $\mathrm{C}_{32} \mathrm{H}_{40} \mathrm{~N}_{4} \mathrm{O}_{8} \mathrm{~S}_{2}: 336.1149$, observed: $336.1154 ;-1.52 \mathrm{ppm}$.

Synthesis of 3,3'-bis(sulfonato)-4,4'-bis(amino)azobenzene (6)

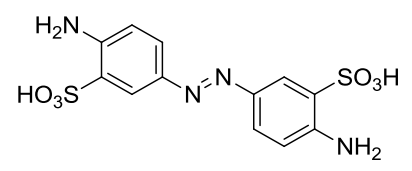

To a suspension of $1.0 \mathrm{~g}(1.5 \mathrm{mmol})$ of compound 5 in $30 \mathrm{~mL}$ of $30 \%$ aqueous methanol, we slowly added $8 \mathrm{~mL}$ of $37 \% \mathrm{HCl}$ in $\mathrm{H}_{2} \mathrm{O}$ followed by $0.81 \mathrm{~mL}$ of anisole. The resulting solution was heated to reflux for $2 \mathrm{~h}$ at $110{ }^{\circ} \mathrm{C}$ and then cooled down to r.t. The solvent was removed us- 
ing rotary evaporator and the resulting solid was washed 5 times with 50 mL DCM. Recrystallization of the product in $\mathrm{EtOH} / \mathrm{H}_{2} \mathrm{O}=95 / 5$ yielded the product as dark purple crystals $(520 \mathrm{mg}$, 92\%). ${ }^{1} \mathrm{H}-\mathbf{N M R}\left(400.0 \mathrm{MHz}, \mathrm{D}_{2} \mathrm{O}\right) \delta 7.99$ (s, $\left.2 \mathrm{H}\right), 7.54$ (d, J=8.4 Hz, $\left.2 \mathrm{H}\right), 6.82(\mathrm{~d}, J=8.4 \mathrm{~Hz}$, $2 \mathrm{H}) \mathrm{ppm} .{ }^{13} \mathrm{C}-\mathbf{N M R}\left(125.7 \mathrm{MHz}, 0.1 \%\right.$ TFA in $\left.\mathrm{D}_{2} \mathrm{O}\right) \delta 147.9,143.8,126.5,126.2,124.7,118.9$ ppm. HRMS-ESI $(\mathrm{m} / z)$ : $(\mathrm{M}-\mathrm{H})$ calc. for: $\mathrm{C}_{12} \mathrm{H}_{11} \mathrm{~N}_{4} \mathrm{O}_{6} \mathrm{~S}_{2}, 371.0125$, observed: 371.0135; -2.42 ppm.

Synthesis of 2-(acetylamino)benzenesulfonic acid (7)

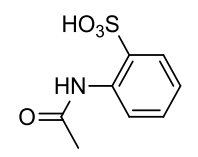

To a solution of 2-aminobenzene sulfonic acid $(0.7 \mathrm{~g}, 4 \mathrm{mmol})$ in $50 \mathrm{~mL}$ of acetic acid, we slowly added $0.36 \mathrm{~mL}$ of acetyl chloride $(5 \mathrm{~mL})$ and stirred the resulting mixture for $2 \mathrm{~h}$ at $100{ }^{\circ} \mathrm{C}$. Removing the solvent by rotary evaporator yielded product 7 as a pale pink solid $(0.86 \mathrm{~g}$, quantitative). ${ }^{1}$ H-NMR (400.0 MHz, DMSO) $\delta 10.31(\mathrm{~s}, 1 \mathrm{H}), 8.21(\mathrm{~d}, J=8.0 \mathrm{~Hz}, 1 \mathrm{H}), 7.62(\mathrm{dd}, J=$ $7.6 \mathrm{~Hz}, J=1.6 \mathrm{~Hz}, 1 \mathrm{H}), 7.24(\mathrm{dt}, J=8.4, J=1.6 \mathrm{~Hz}, 1 \mathrm{H}), 6.96(\mathrm{dt}, J=1.6 \mathrm{~Hz}, J=7.6 \mathrm{~Hz}, 1$ H), 1.99 (s, 3 H) ppm. ${ }^{13}$ C-NMR (100.6 MHz, DMSO) $\delta$ 168.1, 135.4, 130.2, 127.3, 122.7, 120.15, 25.3 ppm. HRMS-ESI $(\mathrm{m} / \mathrm{z})$ : $(\mathrm{M}-\mathrm{H})$ calc. for $\mathrm{C}_{8} \mathrm{H}_{8} \mathrm{NO}_{4} \mathrm{~S}: 214.018$, observed: 214.0176; $1.85 \mathrm{ppm}$.

Synthesis of 2-(1,3-dihydro-2H-isoindol-2-yl)benzenesulfonic acid (9)

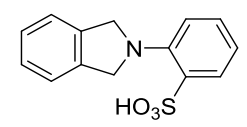

To a suspension of 2-aminobenzene sulfonic acid $(0.34 \mathrm{~g}, 2 \mathrm{mmol})$ in $15 \mathrm{~mL} \mathrm{DMF}$, we added of dibromomethylbenzene $(0.58 \mathrm{~g}, 2.2 \mathrm{mmol})$ and $\mathrm{NaOH}(100 \mathrm{mg}, 2.2 \mathrm{mmol})$. We warmed up the mixture to $90^{\circ} \mathrm{C}$ using oil bath and then stirred the resulting solution for $1 \mathrm{~h}$. After removal of the solvent by rotary evaporator we purified the product by column chromatography. The product was eluted by $\mathrm{DCM} / \mathrm{MeOH}=95 / 5$. Removing the solvent by rotary evaporator yielded the product as grey powder $(0.37 \mathrm{~g}, 68 \%)$. ${ }^{1} \mathbf{H}-\mathbf{N M R}(400.0 \mathrm{MHz}, \mathrm{DMSO}) \delta 7.85(\mathrm{dd}, J=2.4, J=$ $5.6 \mathrm{~Hz}, 1 \mathrm{H}), 7.65(\mathrm{dd}, J=2.4 \mathrm{~Hz}, J=5.6 \mathrm{~Hz}, 1 \mathrm{H}), 7.56(\mathrm{~m}, 2 \mathrm{H}), 7.43(\mathrm{~m}, 4 \mathrm{H}), 5.20(\mathrm{~s}, 4 \mathrm{H})$ 
ppm. ${ }^{13}$ C-NMR (100.5 MHz, DMSO) $\delta$ 139.3, 137.6, 134.4, 132.4, 130.1, 129.3, 128.2, 123.4, 121.6, 63.4 ppm. HRMS-ESI $(\mathrm{m} / \mathrm{z})$ : $(\mathrm{M}-\mathrm{H})$ calc. for $\mathrm{C}_{14} \mathrm{H}_{12} \mathrm{NO}_{3} \mathrm{~S}$ : 274.0543, observed: $274.0541 ;-0.99 \mathrm{ppm}$.

Synthesis of 3,3'-bis(sulfonato)-4,4'-bis(bromoacetamido)azobenzene (11)

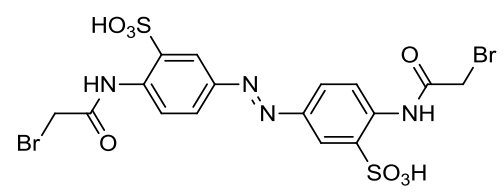

To an ice cold solution of 3,3'-bis(sulfonato)-4,4'-bis(amino)azobenzene (6, $50 \mathrm{mg}, 0.13 \mathrm{mmol}$ ) in $5 \mathrm{~mL}$ of dry DMF, we added $35 \mu \mathrm{L}(0.39 \mathrm{mmol})$ of bromoacetyl bromide, followed by addition of $135 \mu \mathrm{L}$ of DIPEA $(0.78 \mathrm{mmol})$ with vigorous stirring. The solution was warmed up to r.t. in $15 \mathrm{~min}$ and was stirred for an additional $30 \mathrm{~min}$ in that temperature. The progress of the reaction was monitored by LCMS. The reaction mixture was purified by HPLC on a C18 silica column. The product was eluted in $\mathrm{H}_{2} \mathrm{O} / \mathrm{MeCN}: 70 / 30$. After collecting the fractions, the solvent volume was reduced to $1.0 \mathrm{~mL}$ on a rotary evaporator and the solution was lyophilized to yield product 11 as a dark red powder $(63 \mathrm{mg}, 79 \%)$. We note that the same reaction did not yield the desired product when bromoacetyl chloride was used as the acylating agent, because the chloride ion displaced the bromide during the course of the reaction. ${ }^{1} \mathbf{H}-\mathbf{N M R}\left(400.0 \mathrm{MHz}, \mathrm{D}_{2} \mathrm{O}\right) \delta 8.30$ $(\mathrm{d}, J=2 \mathrm{~Hz}, 2 \mathrm{H}), 8.20(\mathrm{~d}, J=8.8 \mathrm{~Hz}, 2 \mathrm{H}), 7.97(\mathrm{~d}, J=8.8 \mathrm{~Hz}, J=2 \mathrm{~Hz}, 2 \mathrm{H}), 4.25(\mathrm{~s}, 4 \mathrm{H})$ ppm. ${ }^{13}$ C-NMR $\left(125.6 \mathrm{MHz}, \mathrm{D}_{2} \mathrm{O}\right) \delta 168.6,149.1,136.7,134.9,127.0,124.9,122.8,30.2 \mathrm{ppm}$. HRMS-ESI (m/z): (M-H) calc. for: $\mathrm{C}_{16} \mathrm{H}_{13} \mathrm{Br}_{2} \mathrm{~N}_{4} \mathrm{O}_{8} \mathrm{~S}_{2}:$ 610.8547, observed: 610.8555; $1.3 \mathrm{ppm}$.

Synthesis of 3,3'-bis(sulfonato)-4,4'-bis(azidoacetamido)azobenzene (12)

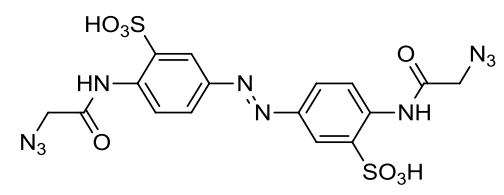

To an ice cold solution of azidoacetic acid $(0.16 \mathrm{~mL}, 2.1 \mathrm{mmol})$ in $0.4 \mathrm{~mL}$ of chloroform, we added $1.8 \mathrm{~mL}$ ( $2.1 \mathrm{mmol}$ ) oxalyl chloride. After stirring for 15 minutes at $0{ }^{\circ} \mathrm{C}$, we added $10 \mu \mathrm{L}$ of DMF to the mixture. The reaction mixture was stirred for 15 minutes on ice, followed by warming up to r.t. and stirring for an additional 90 minutes until the effervescence was stopped. 
We then added this solution to an ice cold solution of 3,3'-bis(sulfonato)-4,4'bis(amino)azobenzene $(6,50 \mathrm{mg}, 0.13 \mathrm{mmol})$ in $5 \mathrm{~mL}$ of dry DMF followed by addition of 0.7 $\mathrm{mL}$ of DIPEA. The reaction was warmed up to r.t. and stirred for $15 \mathrm{~min}$. The reaction mixture was purified by HPLC on a C18 silica column. The product was eluted in $\mathrm{H}_{2} \mathrm{O} / \mathrm{MeCN}=70 / 30$. After collecting the fractions, the solvent volume was reduced to $1.0 \mathrm{~mL}$ on a rotary evaporator and the solution was lyophilized to yield product 12 as a dark red solid (64 mg, 89\%). ${ }^{\mathbf{1}} \mathbf{H}$-NMR (400.0 MHz, DMSO) $\delta 11.06$ (s, $2 \mathrm{H}), 8.55$ (d, J = 8.8 Hz, $2 \mathrm{H}), 8.20$ (d, J = 2.4 Hz, $2 \mathrm{H}), 7.96$ $(\mathrm{dd}, J=8.8 \mathrm{~Hz}, J=2.4 \mathrm{~Hz}, 2 \mathrm{H}), 4.25$ (s, $4 \mathrm{H}$ ) ppm. ${ }^{13} \mathrm{C}-\mathbf{N M R}(125.7 \mathrm{MHz}, \mathrm{DMSO}) \delta 166.1$, 146.8, 136.8, 136.4, 126.0, 120.16, 119.4, 52.3 ppm. HRMS-ESI $(\mathrm{m} / \mathrm{z})$ : (M-H) calc. for: $\mathrm{C}_{16} \mathrm{H}_{13} \mathrm{~N}_{10} \mathrm{O}_{8} \mathrm{~S}_{2}$ : 537.0365, observed: 537.0369; -0.86 ppm.

Synthesis of 3,3'-bis(sulfonato)-4,4'-bis(prop-2-ynoylamido)azobenzene (13)

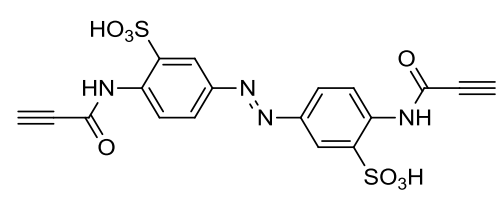

To $0.10 \mathrm{~mL}$ of ice cold propiolic acid $(0.01 \mathrm{~g}, 1.4 \mathrm{mmol})$, we slowly added $0.11 \mathrm{~mL}(0.16 \mathrm{~g}, 1.4$ mmol) of oxalyl chloride at r.t. After stirring for $15 \mathrm{~min}$, we cooled down the reaction to $0{ }^{\circ} \mathrm{C}$ on ice bath and added $10 \mu \mathrm{L}$ of dry DMF. The reaction mixture was stirred on ice for $15 \mathrm{~min}$ and then for an additional $45 \mathrm{~min}$ at r.t. until effervescence stopped. We then added this solution drop-wise, using a Gilson P200 pipette, to a solution of 3,3'-bis(sulfonato)-4,4'bis(amino)azobenzene $(6,20 \mathrm{mg}, 0.05 \mathrm{mmol})$ in $2 \mathrm{~mL}$ of $1.0 \mathrm{M}$ sodium carbonate in water, at r.t. over $15 \mathrm{~min}$. We stirred the reaction mixture for an additional $30 \mathrm{~min}$ at r.t. The reaction mixture was purified by HPLC on a C18 silica column. The product was eluted in $\mathrm{H}_{2} \mathrm{O} / \mathrm{MeCN}=60 / 40$. After collecting the fractions, the solvent volume was reduced to $1.0 \mathrm{~mL}$ on a rotary evaporator and the solution was lyophilized to yield product as a yellow-orange solid $(17.4 \mathrm{mg}, 69 \%)$. ${ }^{1} \mathbf{H}$ NMR (400.0 MHz, DMSO) $\delta 8.45(\mathrm{~d}, J=8.8 \mathrm{~Hz}, 2 \mathrm{H}), 8.20(\mathrm{~d}, J=2.4 \mathrm{~Hz}, 2 \mathrm{H}), 7.98(\mathrm{dd}, J=$ $8.8 \mathrm{~Hz}, J=2.4 \mathrm{~Hz}, 2 \mathrm{H}), 4.57(\mathrm{~s}, 2 \mathrm{H}) \mathrm{ppm} .{ }^{13} \mathrm{C}-\mathbf{N M R}\left(125.7 \mathrm{MHz}, \mathrm{D}_{2} \mathrm{O}, 10 \% \mathrm{DMSO}-d_{6}\right) \delta$ 152.8, 149.2, 136.2, 134.8, 127.0, 125.2, 122.9, 79.1, 77.3 ppm. HRMS-ESI (m/z): (M-H) calc. for: $\mathrm{C}_{18} \mathrm{H}_{11} \mathrm{~N}_{4} \mathrm{O}_{8} \mathrm{~S}_{2}$ : 475.0024, observed: 475.0035; 2.4 ppm. 
Synthesis of 3,3'-bis(sulfonato)-4,4'-bis(buta-2,3-dienoylamido)azobenzene (14)

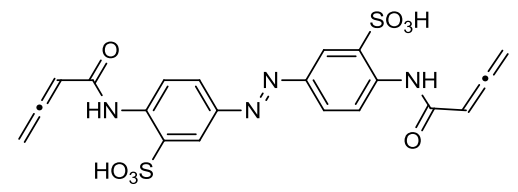

To a suspension of 2-butynoic acid (250 mg, $3 \mathrm{mmol})$ in $0.5 \mathrm{~mL}$ chloroform, we slowly added $0.26 \mathrm{~mL}$ of oxalyl chloride. After stirring for $15 \mathrm{~min}$ at r.t., we cooled down the reaction to $0{ }^{\circ} \mathrm{C}$ on ice bath and added $20 \mu \mathrm{L}$ of dry DMF. The reaction mixture was stirred on ice for $15 \mathrm{~min}$ and then for an additional $90 \mathrm{~min}$ at r.t. until effervescence stopped and solids dissolved completely. We then added this solution drop-wise, using a Gilson P200 pipette to a solution of 3,3'bis(sulfonato)-4,4'-bis(amino)azobenzene $(\mathbf{6}, 100 \mathrm{mg}, 0.27 \mathrm{mmol}$ ) in $20 \mathrm{~mL}$ of saturated sodium bicarbonate in water, at r.t. over $15 \mathrm{~min}$. The reaction was stirred for an additional $30 \mathrm{~min}$ at r.t. The reaction mixture was washed with $2 \times 20 \mathrm{~mL}$ DCM, concentrated to $5 \mathrm{~mL}$ on a rotary evaporator and purified by HPLC on a $\mathrm{C} 18$ silica column. The product was eluted in $\mathrm{H}_{2} \mathrm{O} / \mathrm{MeCN}=$ 70/30. After collecting the fractions, the solvent volume was reduced to $1.0 \mathrm{~mL}$ on a rotary evaporator and the solution was lyophilized to yield product 14 as a yellow-orange solid ( $88 \mathrm{mg}$, 65\%). ${ }^{1} \mathrm{H}$-NMR (399.8 MHz, $\left.\mathrm{D}_{2} \mathrm{O}\right) \delta 8.25(\mathrm{~d}, J=2.4 \mathrm{~Hz}, 2 \mathrm{H}), 8.23(\mathrm{~d}, J=9.2 \mathrm{~Hz}, 2 \mathrm{H}), 7.85$ $(\mathrm{dd}, J=2.4 \mathrm{~Hz}, J=9.2 \mathrm{~Hz}, 2 \mathrm{H}), 5.86(\mathrm{t}, J=6.4 \mathrm{~Hz}, 2 \mathrm{H}), 5.58(\mathrm{~d}, J=6.4 \mathrm{~Hz}, 4 \mathrm{H}) \mathrm{ppm} .{ }^{13} \mathrm{C}-$ NMR $\left(125.7 \mathrm{MHz}, \mathrm{D}_{2} \mathrm{O}\right) \delta 213.8,167.0,148.3,137.3,133.4,127.1,123.4,122.8,91.5,83.2$ ppm. HRMS-ESI $(\mathrm{m} / \mathrm{z})$ : (M-H) calc. for $\mathrm{C}_{20} \mathrm{H}_{15} \mathrm{~N}_{4} \mathrm{O}_{8} \mathrm{~S}_{2}$ : 503.0345, observed: 503.0337; 1.57 ppm.

Synthesis of cyclized peptide ACGFERETCG (16)

To a $1 \mathrm{~mL}$ solution of $5.5 \mathrm{mg}$ of peptide 36 (with amino acid sequence of $\mathrm{NH}_{2}-$ ACGFERERTCG-CO $\left.{ }_{2} \mathrm{H}, 0.004 \mathrm{mmol}\right)$ in Tris buffer $(50 \mathrm{mM}, \mathrm{pH} 8.5)$ we added $2.2 \mathrm{mg}$ of BSBDA (14), followed by $40 \mu \mathrm{L}$ of $100 \mathrm{mM}$ aqueous TCEP solution. The solution was incubated for 15 minutes in dark at r.t. before purification by HPLC over C18 column. Collected fractions were concentrated to $1 \mathrm{~mL}$ using rotary evaporator and then lyophilized to yield the product as a yellow powder $(4.2 \mathrm{mg}, 82 \%)$. HRMS-ESI $(\mathrm{m} / \mathrm{z})$ : $(\mathrm{M}-2 \mathrm{H})^{-2}$ calc. for $\mathrm{C}_{68} \mathrm{H}_{91} \mathrm{~N}_{21} \mathrm{O}_{25} \mathrm{~S}_{4}$ : 864.7694, observed: 864.7715; 2.37 ppm. 


\begin{tabular}{|l|l|l|l|l|l|l|l|l|l|l|}
\hline Residue & $\begin{array}{l}\mathbf{N H} \\
(\#)\end{array}$ & $\begin{array}{l}\mathbf{N H} \\
(\boldsymbol{\delta})\end{array}$ & $\begin{array}{l}\mathbf{H} \boldsymbol{\alpha} \\
(\#)\end{array}$ & $\begin{array}{l}\mathbf{H} \boldsymbol{\alpha} \\
\mathbf{( \delta )}\end{array}$ & $\mathbf{H} \boldsymbol{\beta}(\#)$ & $\mathbf{H} \boldsymbol{\beta}(\boldsymbol{\delta})$ & $\mathbf{H} \boldsymbol{( \# )}$ & $\mathbf{H} \gamma(\boldsymbol{\delta})$ & $\mathbf{H} \boldsymbol{\delta}(\#)$ & $\mathbf{H} \boldsymbol{\delta}(\boldsymbol{\delta})$ \\
\hline Ala & 1,2 & --- & 6 & 4.1 & $3,4,5$ & 1.48 & --- & --- & --- & --- \\
\hline Cys & 7 & 8.77 & 8 & 4.65 & 92,93 & 3.22 & --- & --- & --- & --- \\
\hline Gly & 9 & 8.33 & 10,11 & 3.95 & --- & --- & --- & --- & --- & --- \\
\hline Phe & 12 & 7.64 & 13 & 4.35 & 14,15 & 2.82 & --- & --- & --- & --- \\
\hline Glu & 21 & 8.04 & 22 & 4.12 & 23,24 & $1.89,1.78$ & 25,26 & 2.23 & --- & --- \\
\hline Arg & 28 & 7.87 & 29 & 4.13 & 30,31 & $1.56,1.65$ & 32,33 & 1.4 & 34,35 & 2.98 \\
\hline Glu & 40 & 8.18 & 41 & 4.22 & 42,43 & $1.9,2.0$ & 44,45 & 2.4 & --- & --- \\
\hline Arg & 47 & 8.2 & 48 & 4.27 & 49,50 & $1.62,1.73$ & 51,52 & 1.41 & 53,54 & 2.96 \\
\hline Thr & 59 & 7.96 & 60 & 4.25 & 62 & 4.2 & $63-65$ & 1.1 & --- & --- \\
\hline Cys & 66 & 8.21 & 67 & 4.65 & 68,69 & 3.21 & --- & --- & --- & --- \\
\hline Gly & 70 & 8.37 & 71,72 & 3.67 & --- & --- & --- & --- & --- & --- \\
\hline BSBDA & 78 & 9.95 & --- & --- & --- & --- & --- & --- & --- & --- \\
\hline BSBDA & 87 & 9.93 & --- & --- & --- & --- & --- & --- & --- & --- \\
\hline
\end{tabular}

\begin{tabular}{|l|l|l|l|}
\hline Residue & functionality & $\mathbf{H}(\#)$ & $\mathbf{H}(\boldsymbol{\delta})$ \\
\hline Arg & guanidine & $55-58,36-39$ & --- \\
\hline Phe & aromatic & $16,17,18,19,20$, & $7.15,7.15,7.17$ \\
\hline BSBDA & aromatic & $79-81,83-85$ & $\begin{array}{l}8.28,8.27,8.21, \\
7.88,7.85\end{array}$ \\
\hline BSBDA & alkene & 74,75 & $5.51,5.54$ \\
\hline BSBDA & alkene & 90,91 & $5.29,5.31$ \\
\hline BSBDA & sulfonate & 82,86 & --- \\
\hline BSBDA & methylene & 76,77 & $3.40,3.45$ \\
\hline Gly & carboxylic acid & 73 & -- \\
\hline Thr & Hydroxyl & 61 & --- \\
\hline Glu & carboxylic acid & 27,46 & --- \\
\hline
\end{tabular}

Table S1. NMR signal of protons in the cyclized peptide 16. The hydrogens highlighted in grey in table were exchanged with deuterium and hence were not detectable. Chemical shifts are reported in ppm. 1D-NMR, TOCSY, COSY and ROESY were run using a $3.5 \mathrm{mM}$ peptide solution sample in $\mathrm{H}_{2} \mathrm{O} / \mathrm{D}_{2} \mathrm{O}(90 / 10)$ supplemented with $0.1 \%$ trifluoroacetic acid. For the structure of the peptide and hydrogen numbering see Scheme 2 (next page). 


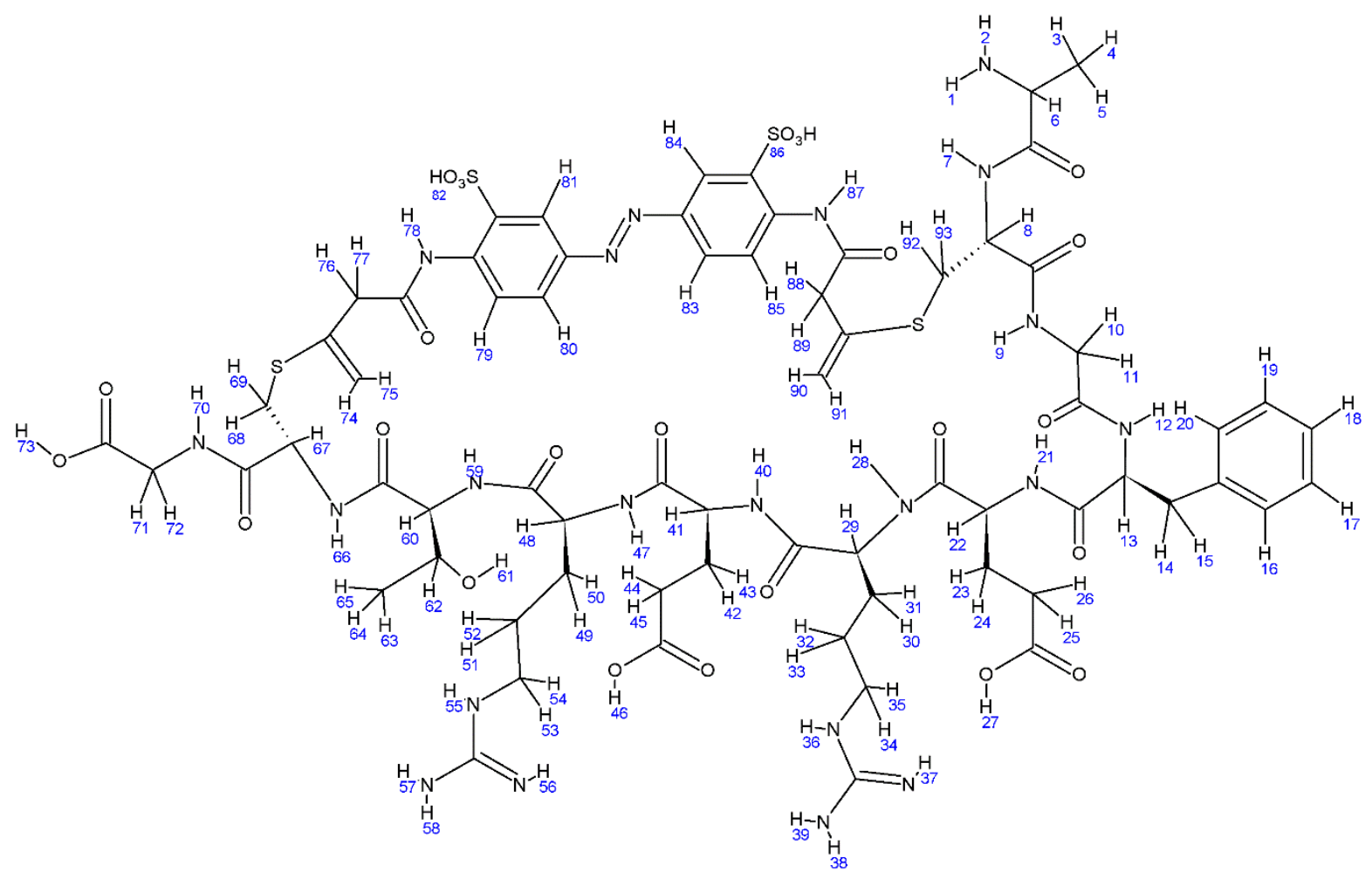

Scheme 2. Structure of $\mathbf{1 6}$ with explicit hydrogens. 
TOCSY-NMR of cyclized peptide ACGFERETCG (16)

For numbering of protons, see Table S1 and Scheme 2.

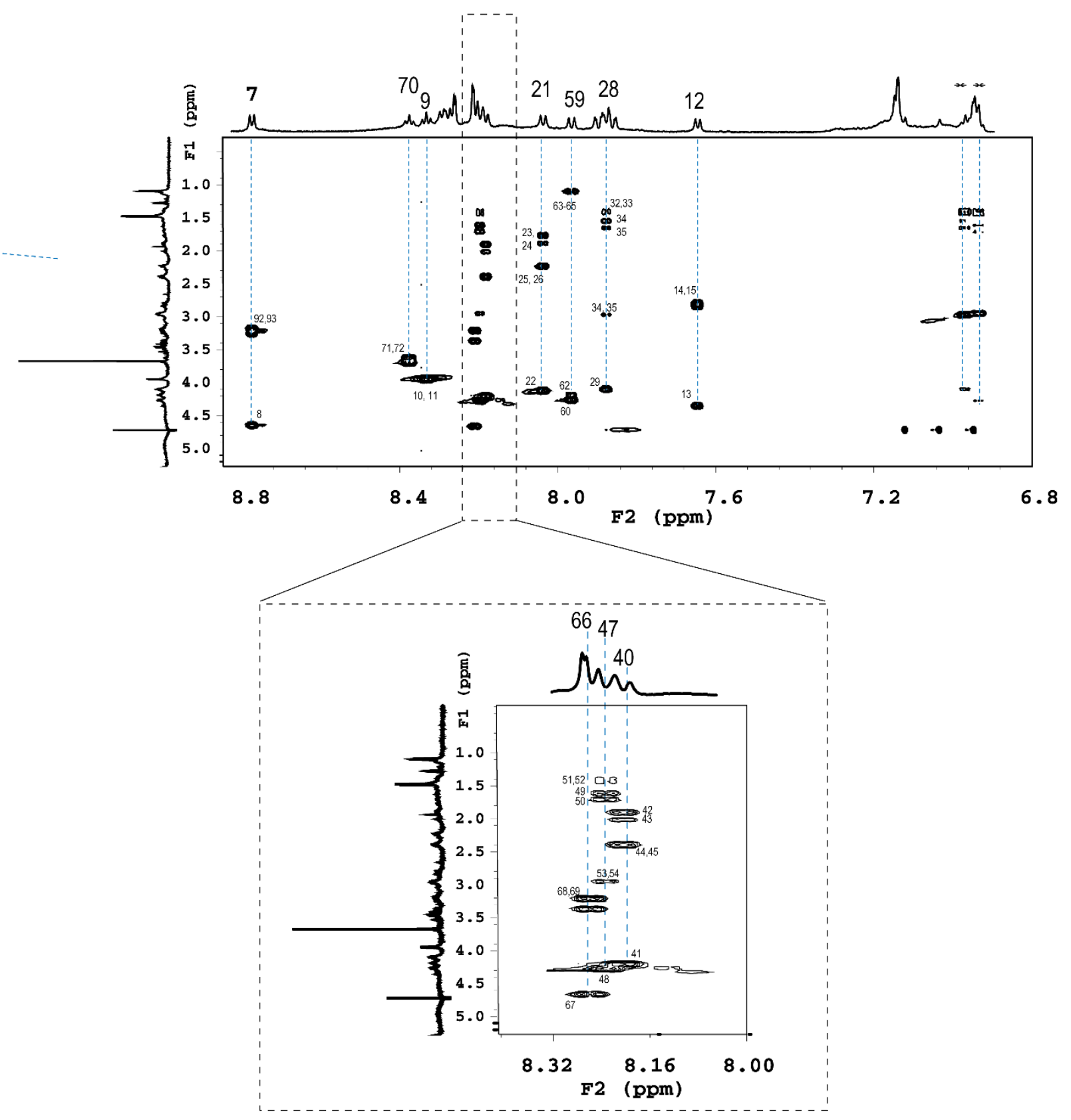


${ }^{1} \mathrm{H}$ - NMR of cyclized peptide ACGFERETCG (16)

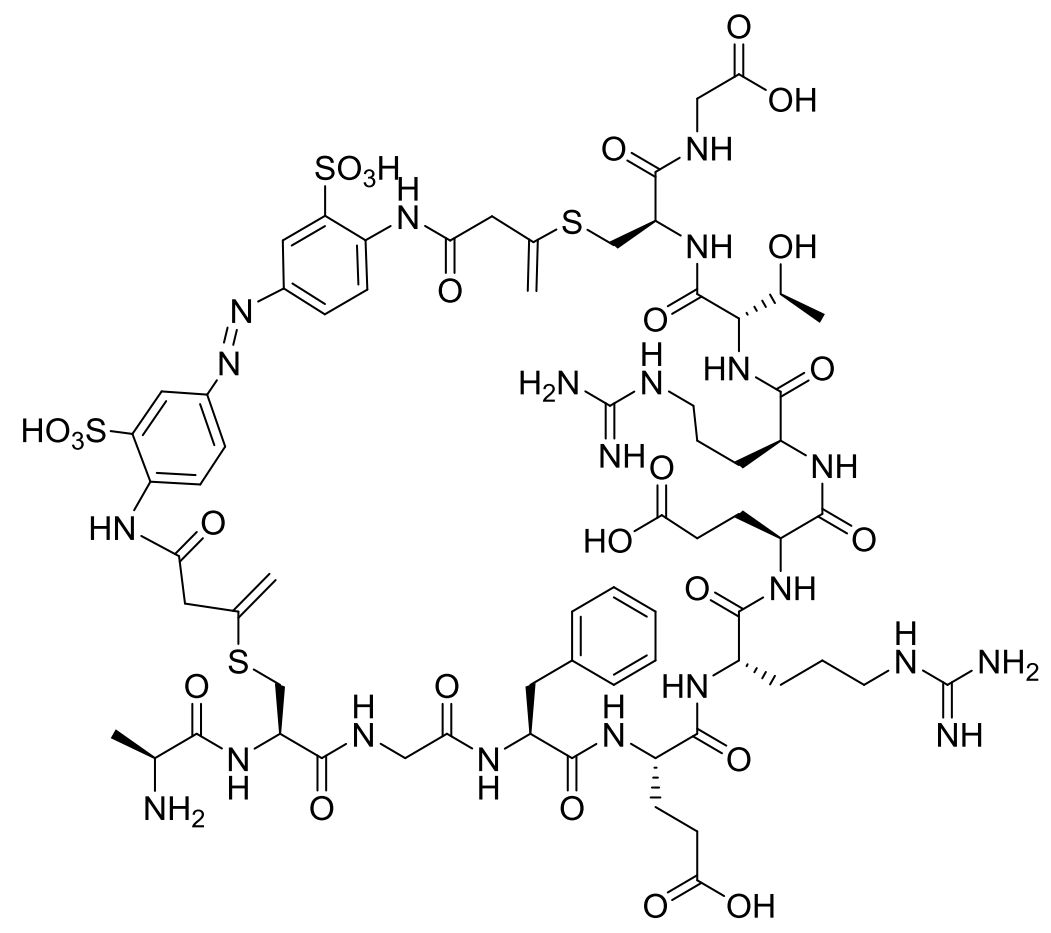

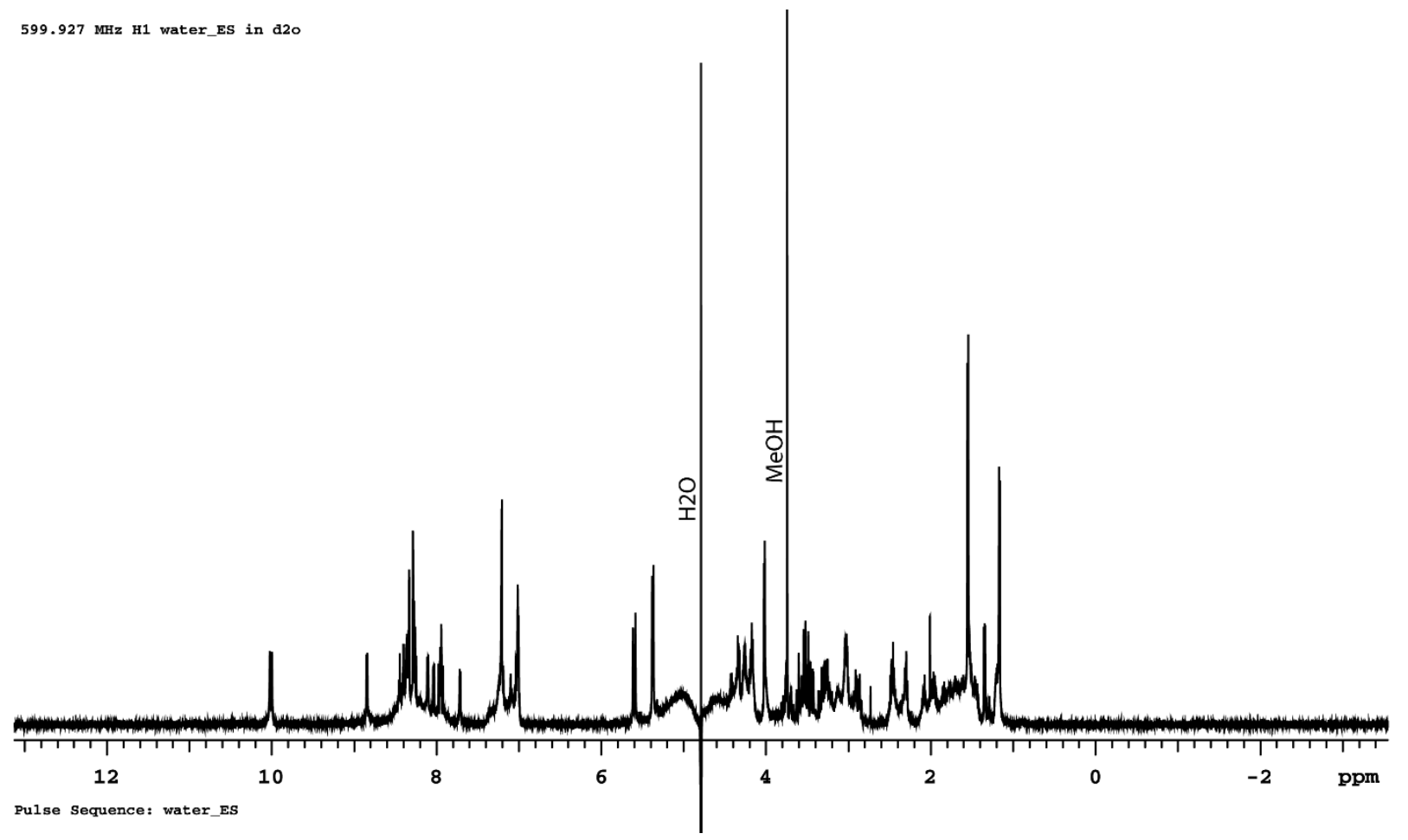




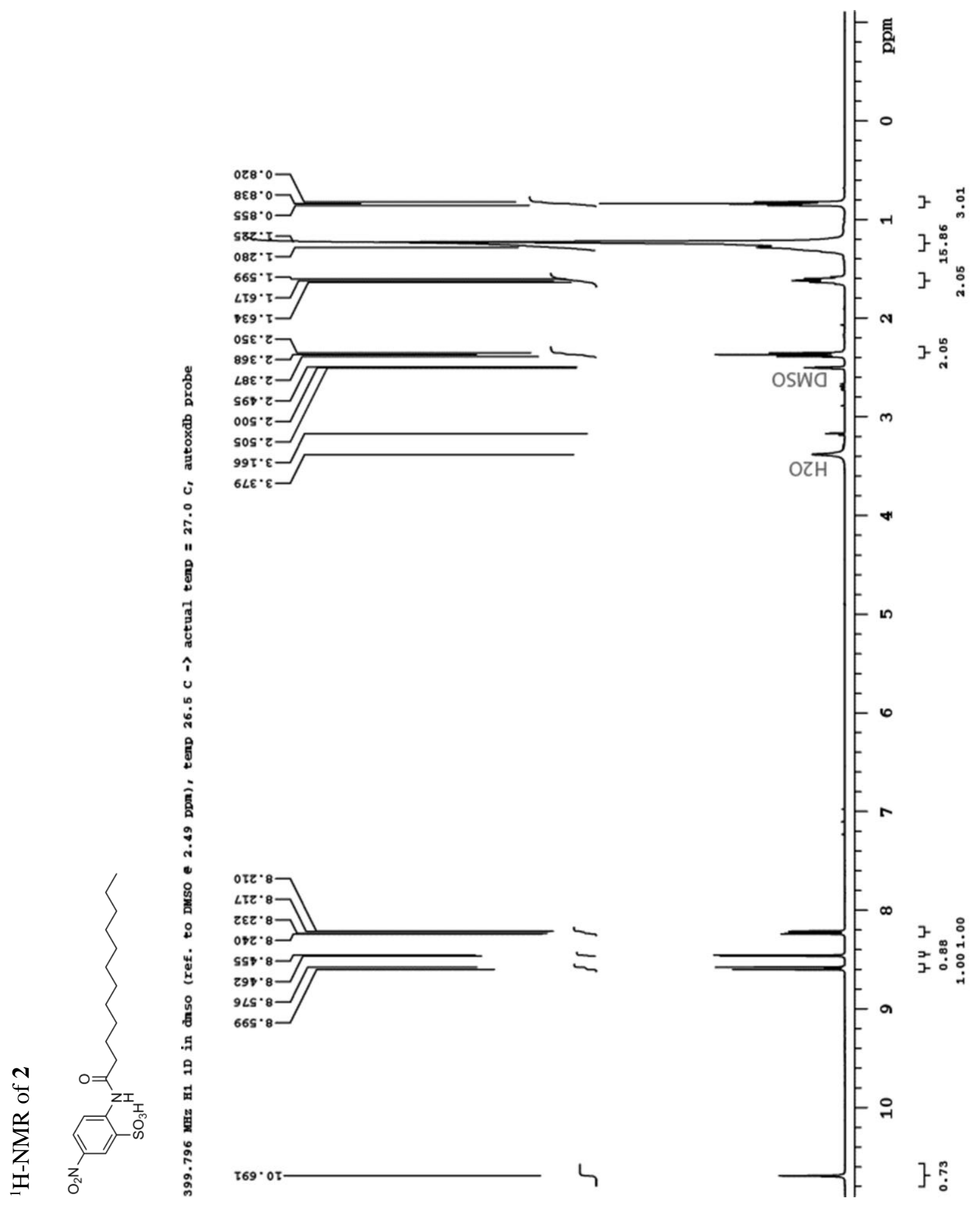



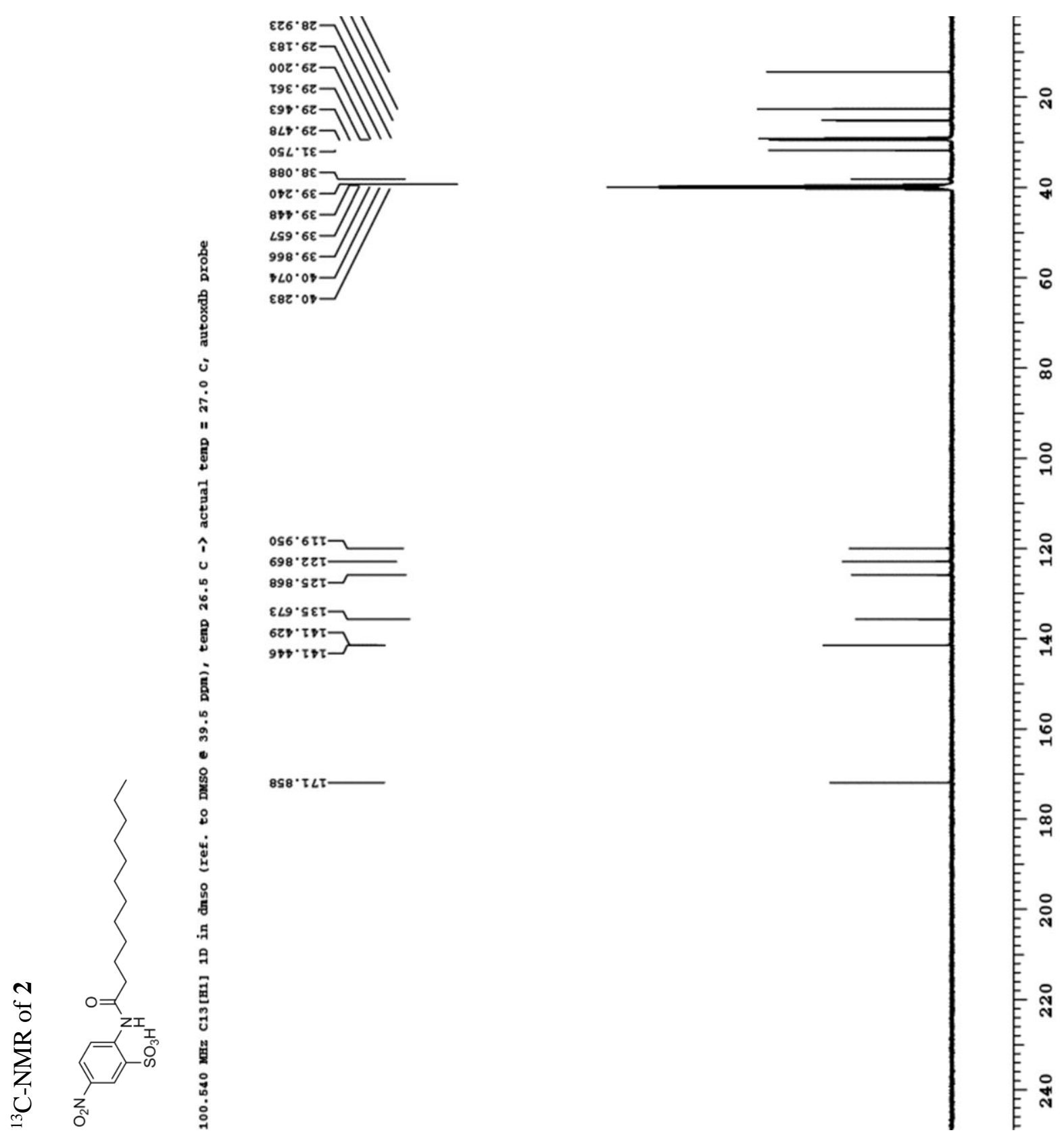


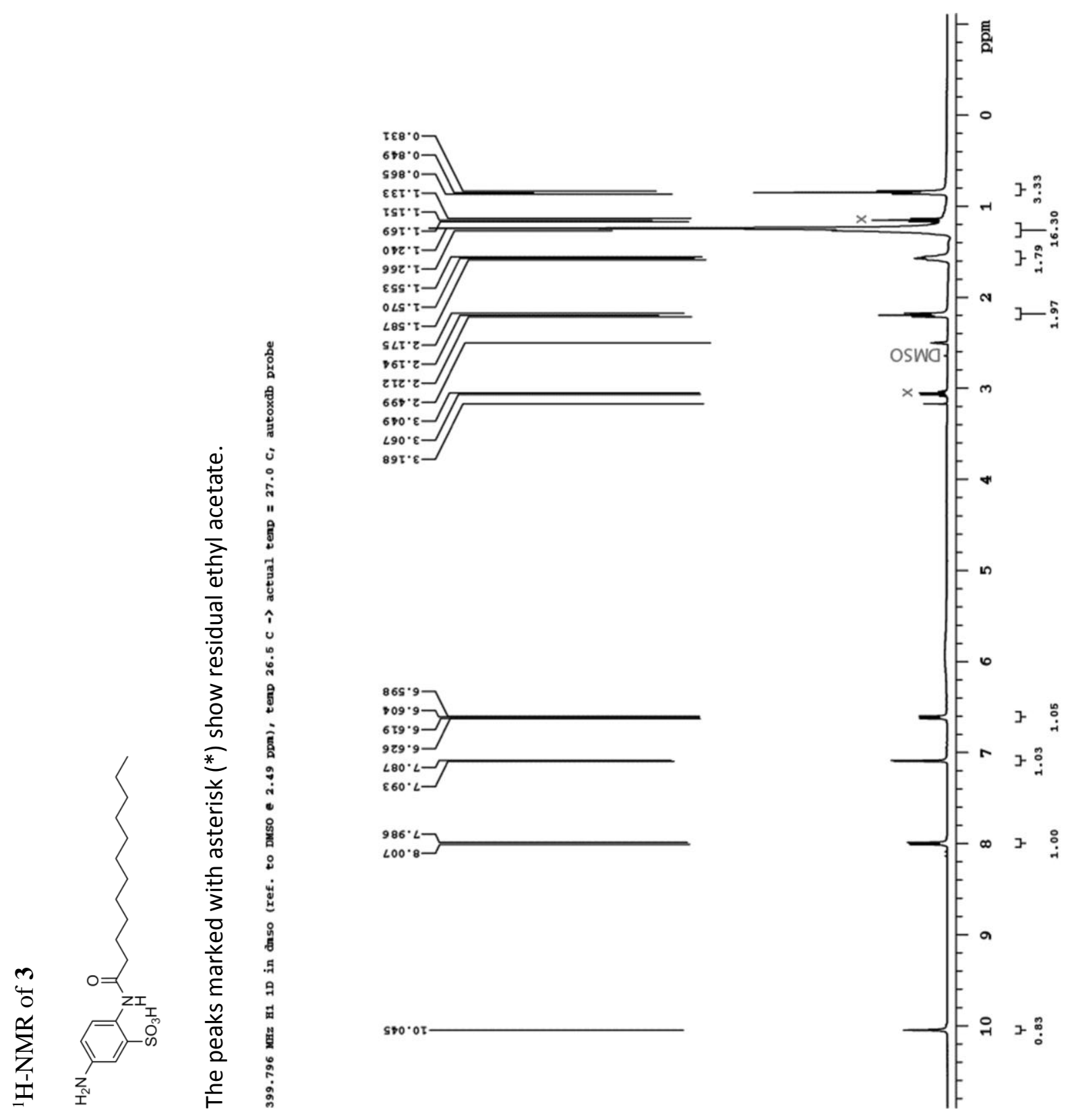




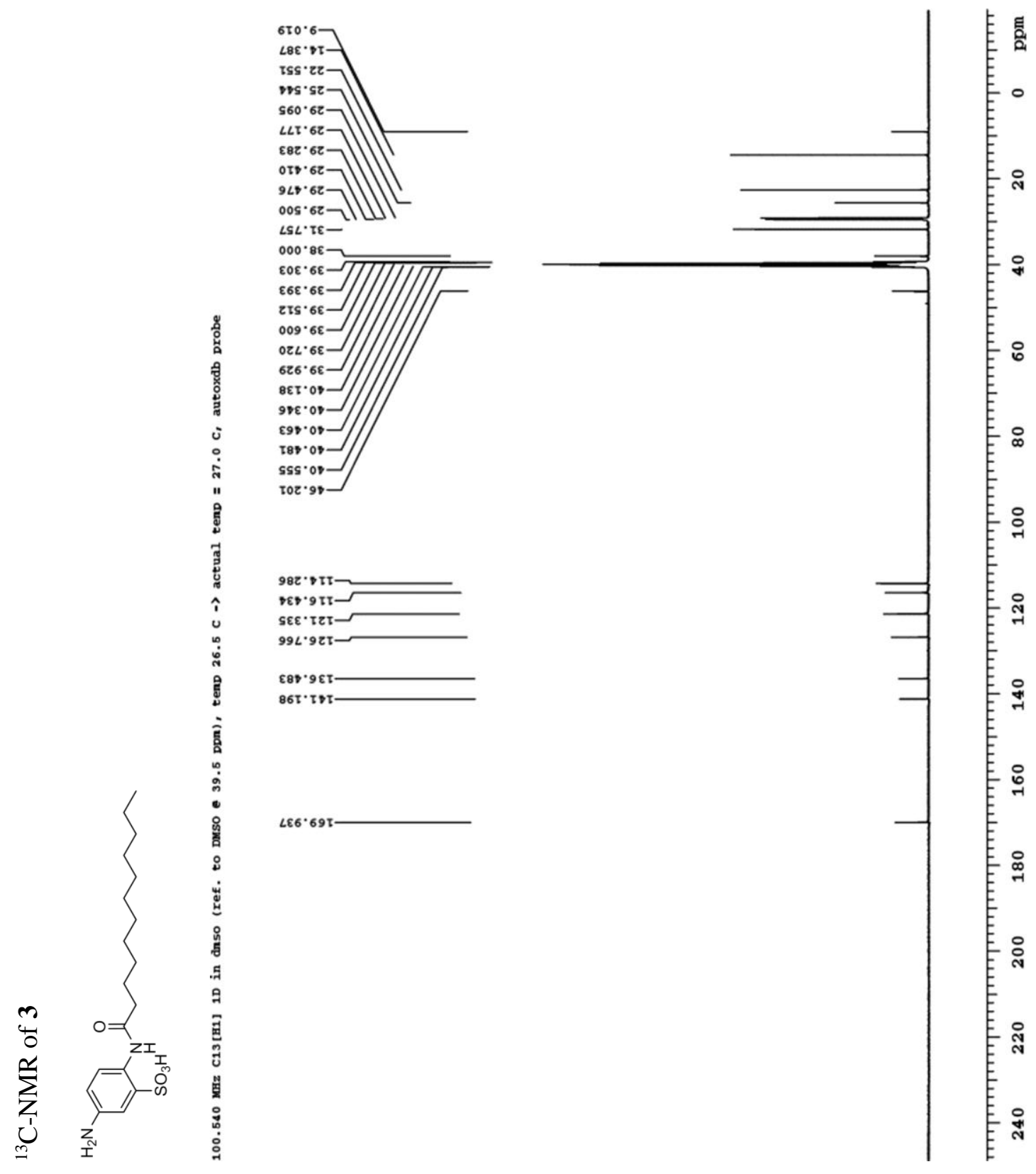




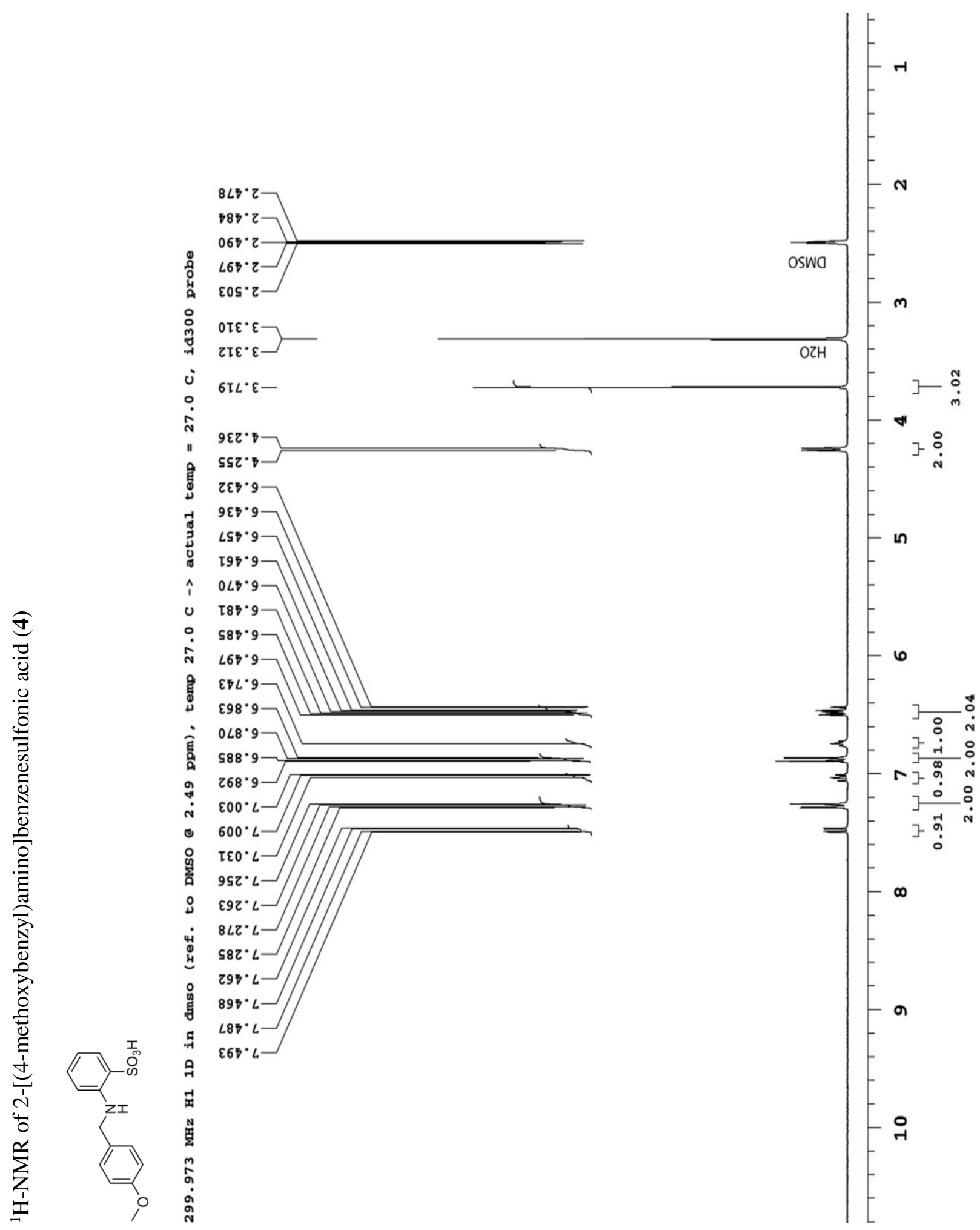




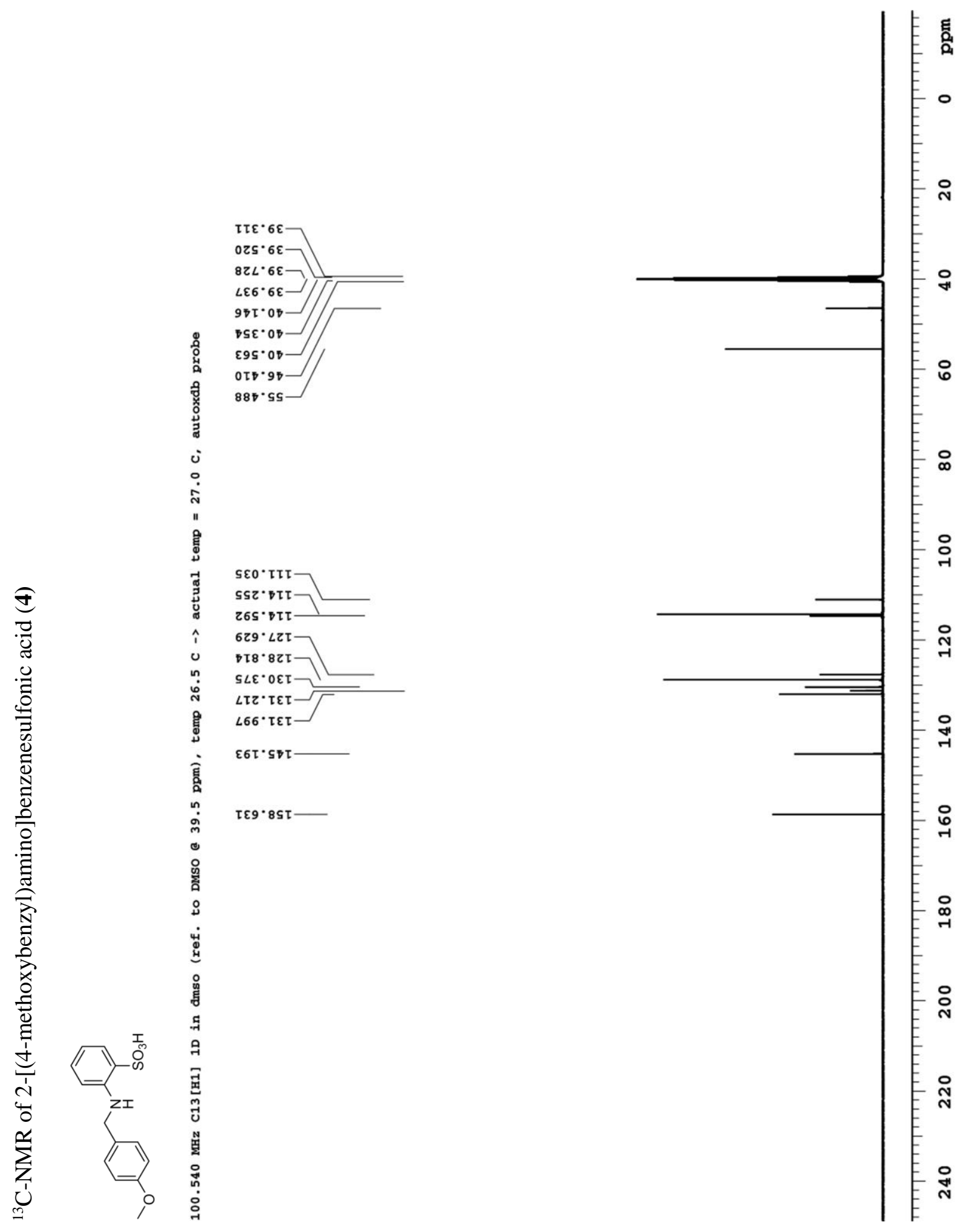



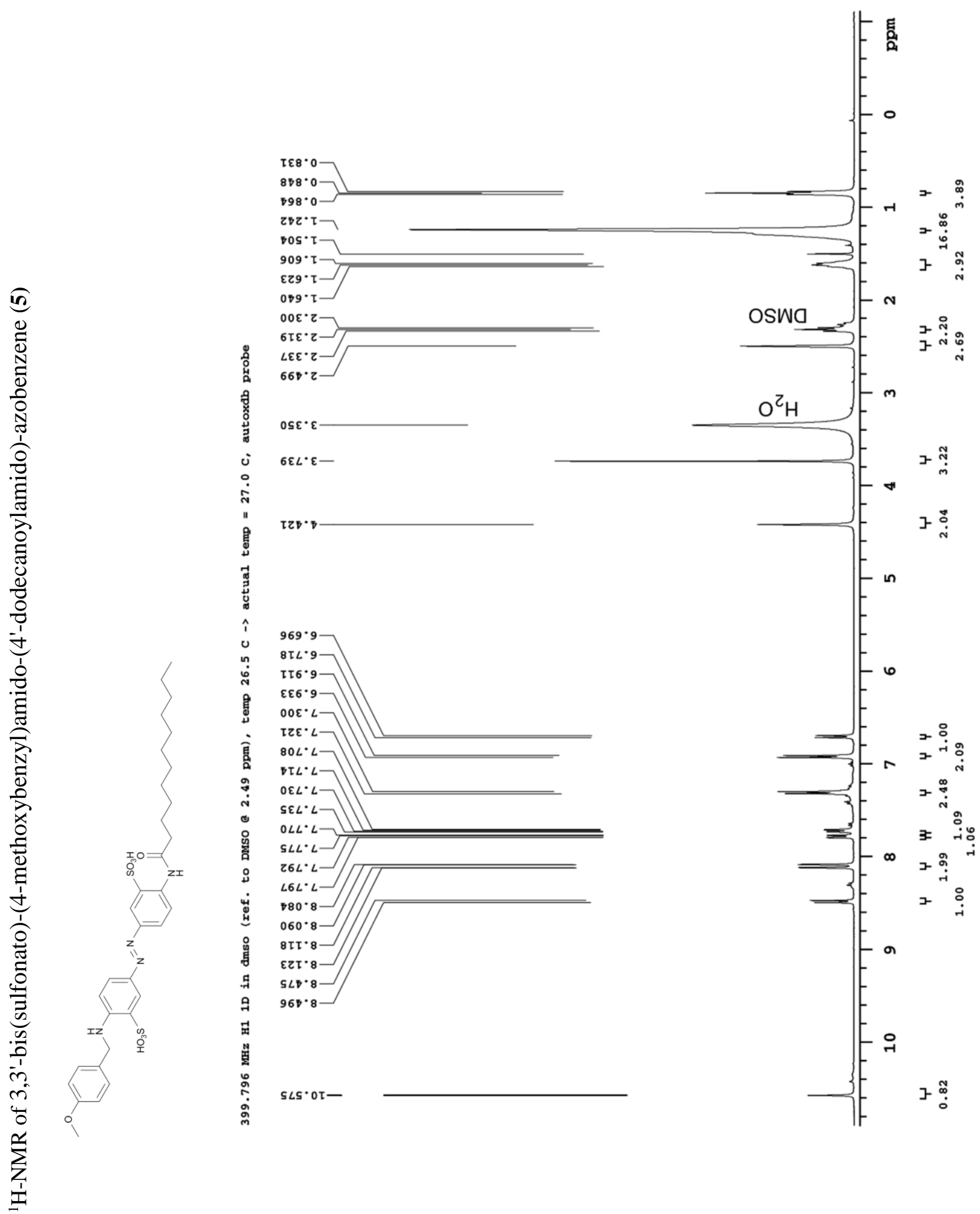

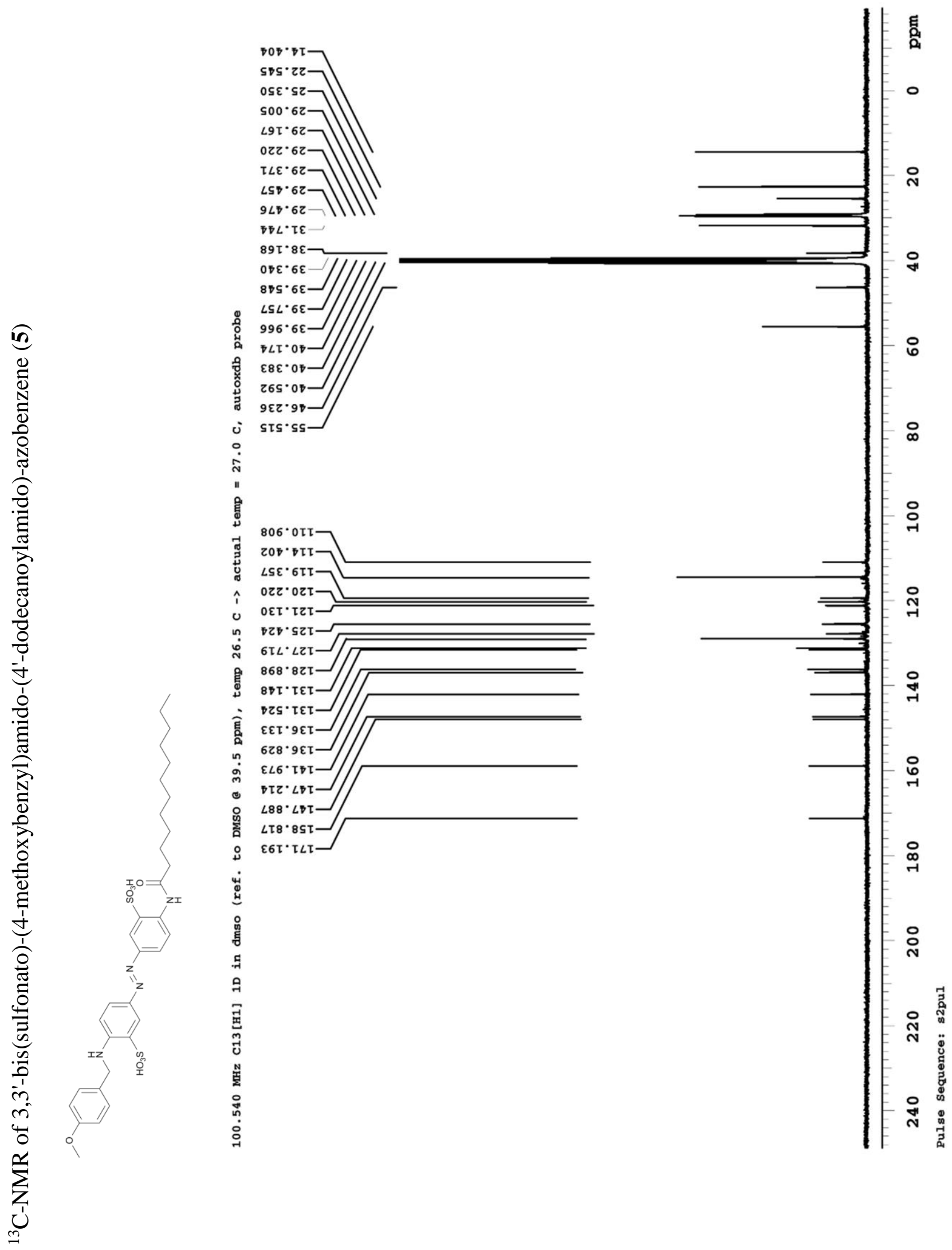
${ }^{1}$ H-NMR of 3,3'-bis(sulfonato)-4,4'-bis(amino)azobenzene (6)<smiles>Nc1ccc(N=Nc2ccc(N)c(S(=O)(=O)O)c2)cc1S(=O)(=O)O</smiles>
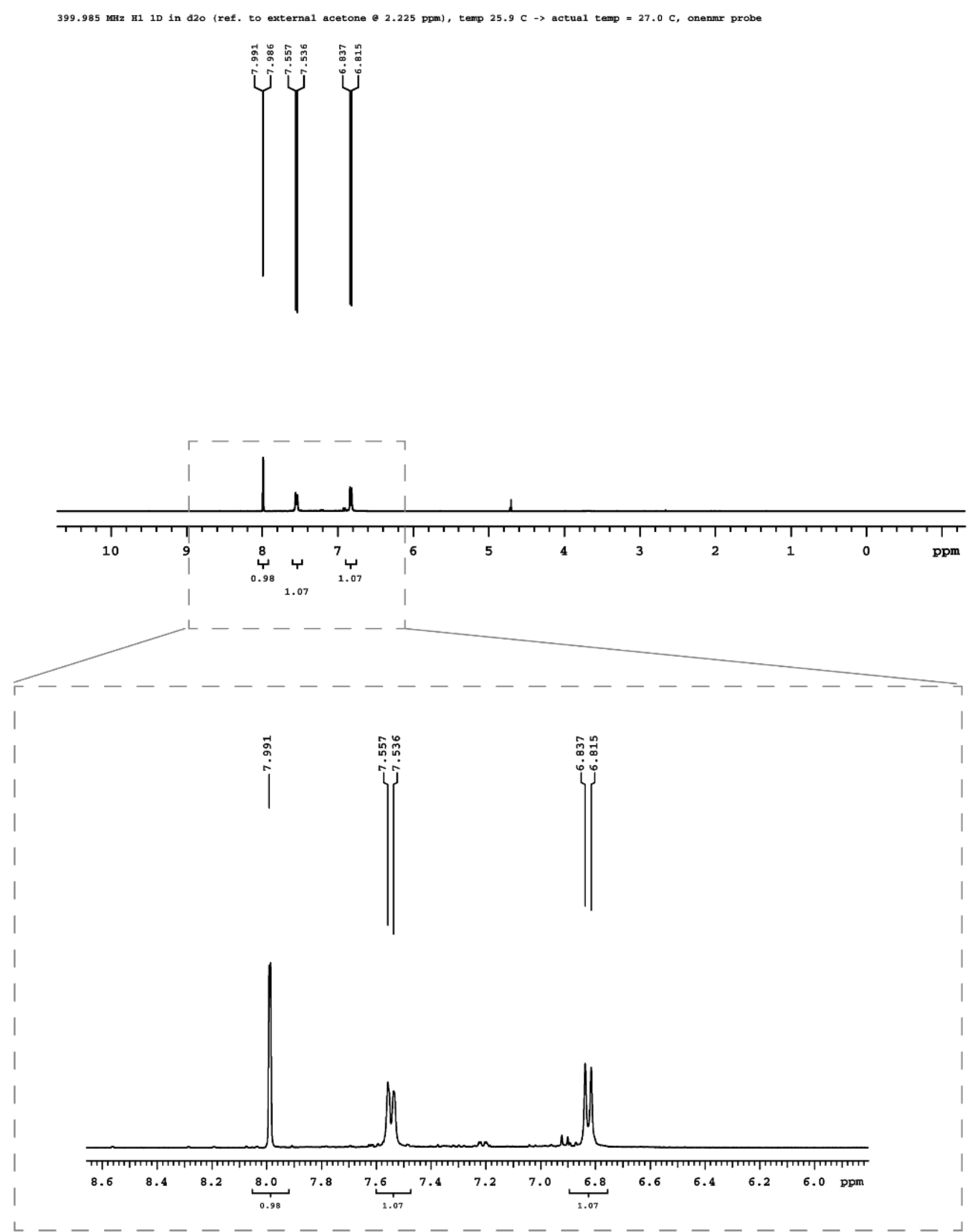

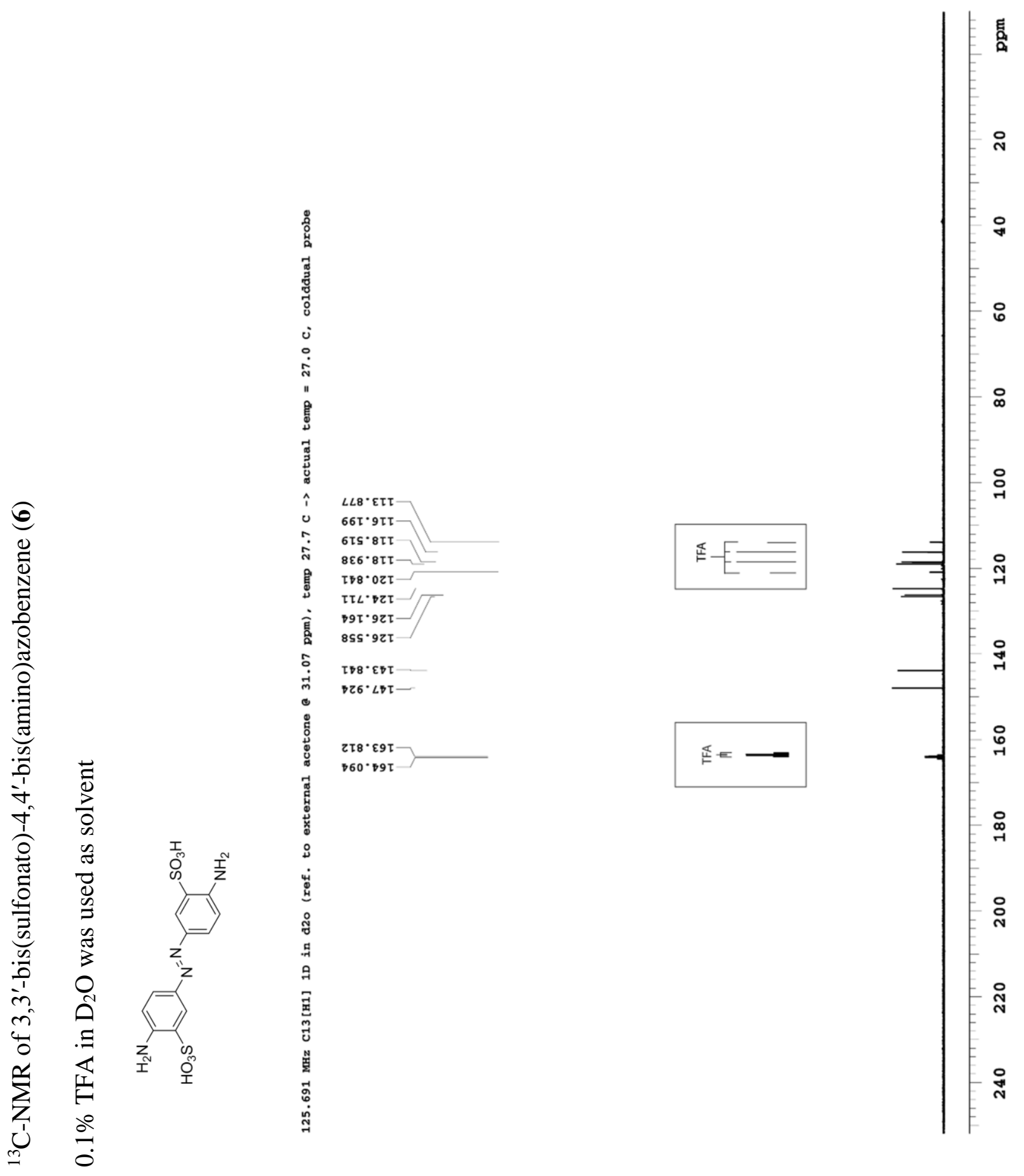


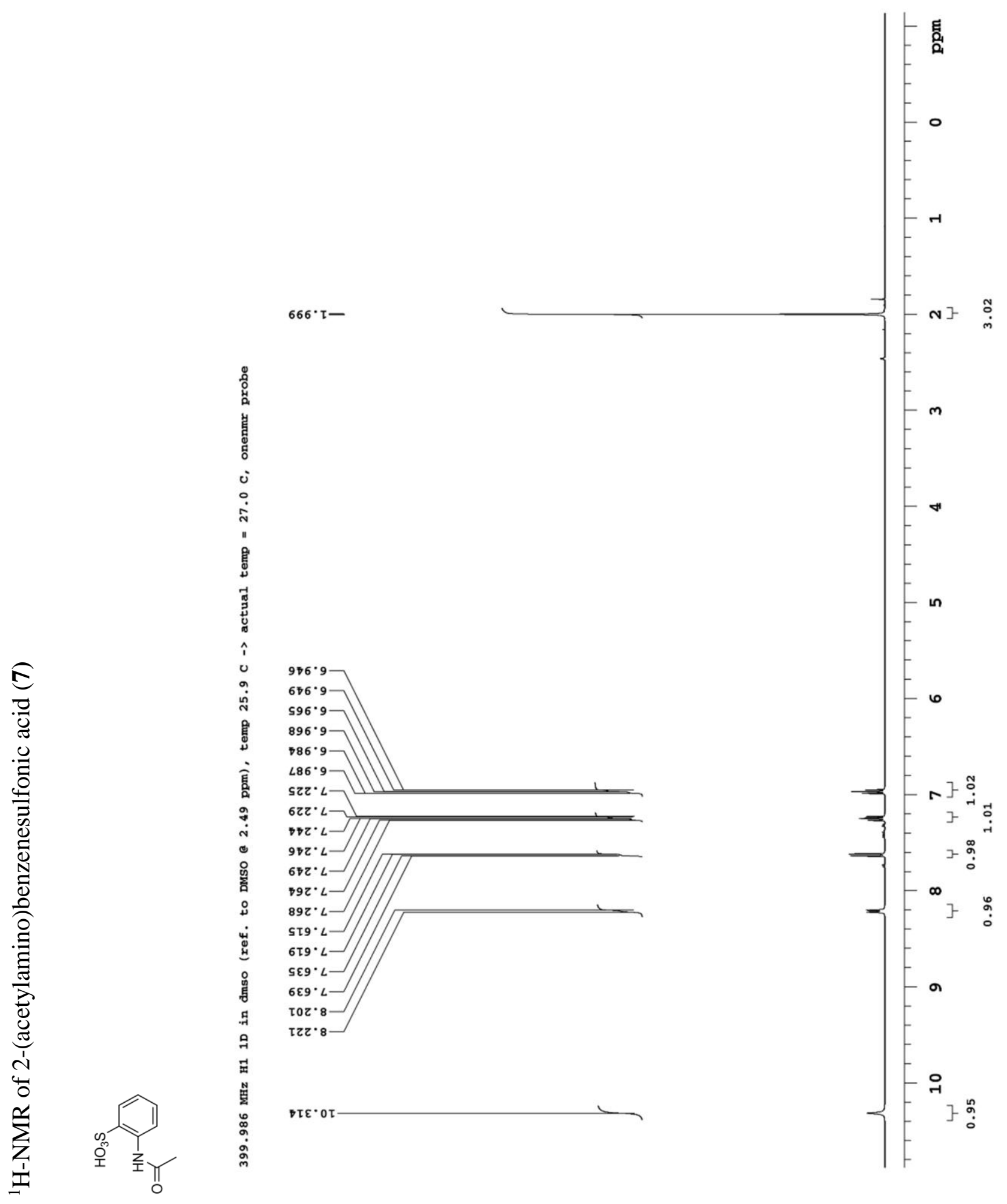


${ }^{1} \mathrm{H}-\mathrm{NMR}$ of 2-(acetylamino)benzenesulfonic acid (7)

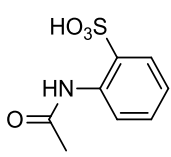

$100.588 \mathrm{MHz}$ C13[H1] 1D in dmso (ref. to DMSO e $39.5 \mathrm{ppm}$ ), temp $25.9 \mathrm{C} \rightarrow$ actual temp $=27.0 \mathrm{C}$, onenmr probe
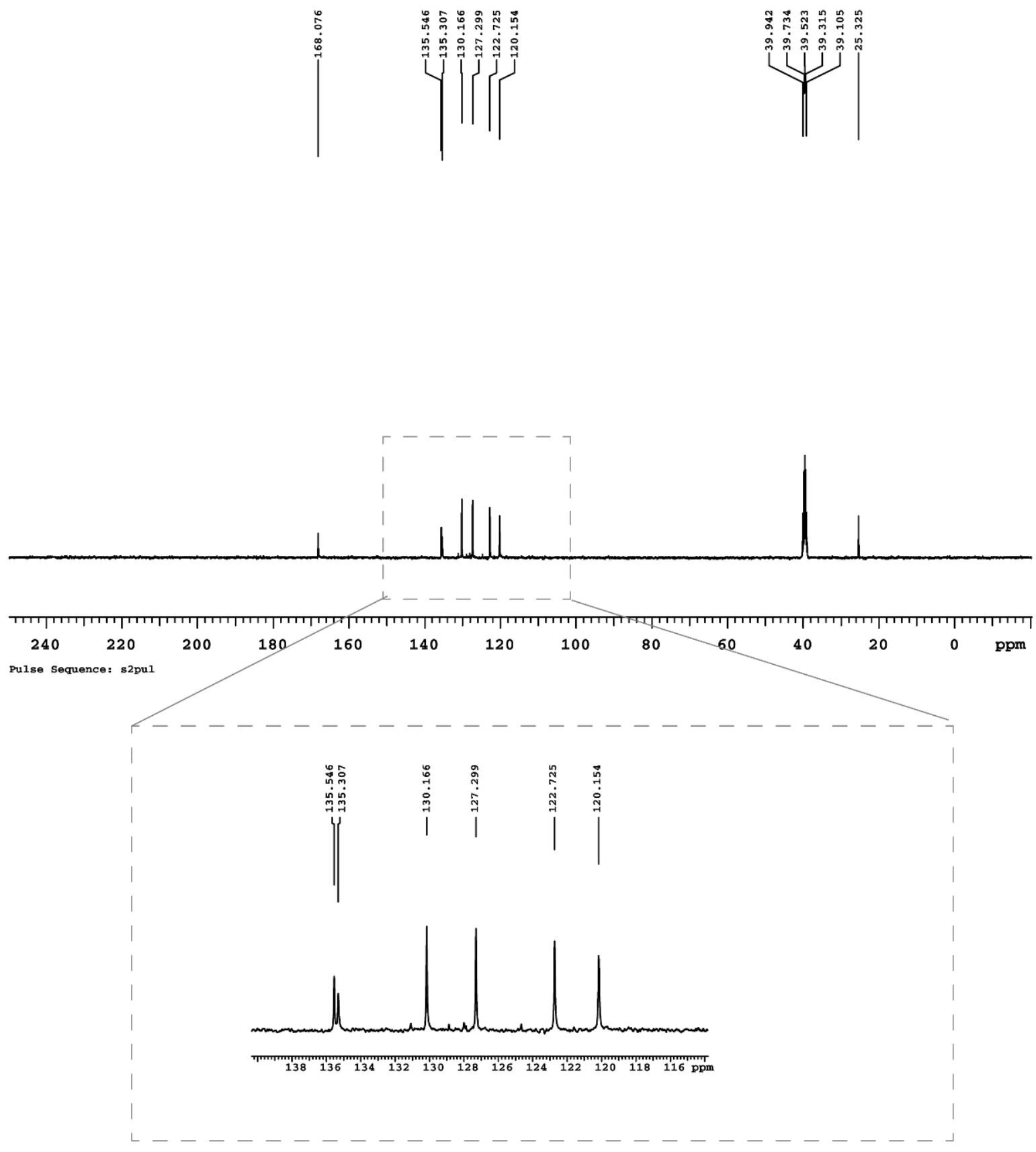

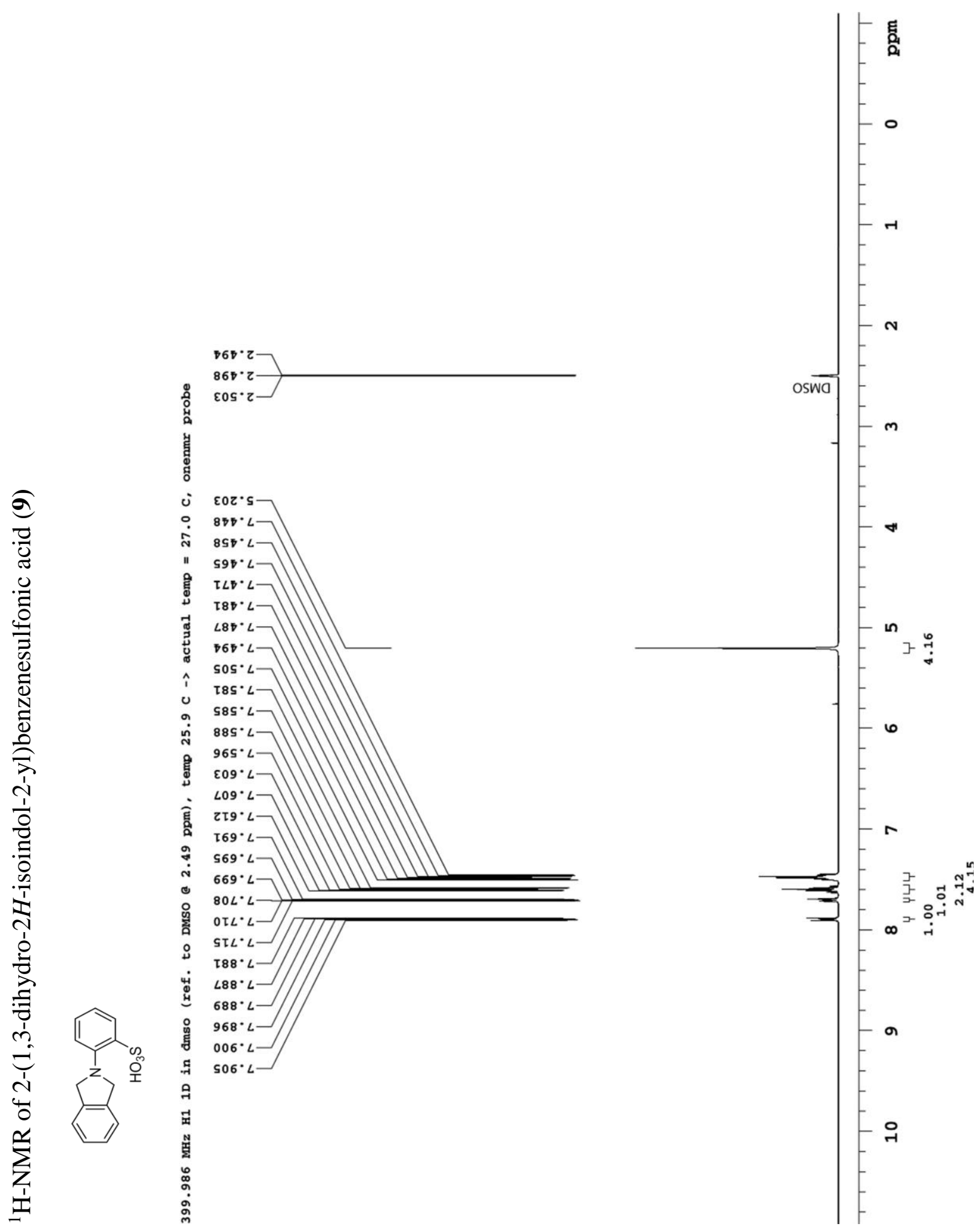


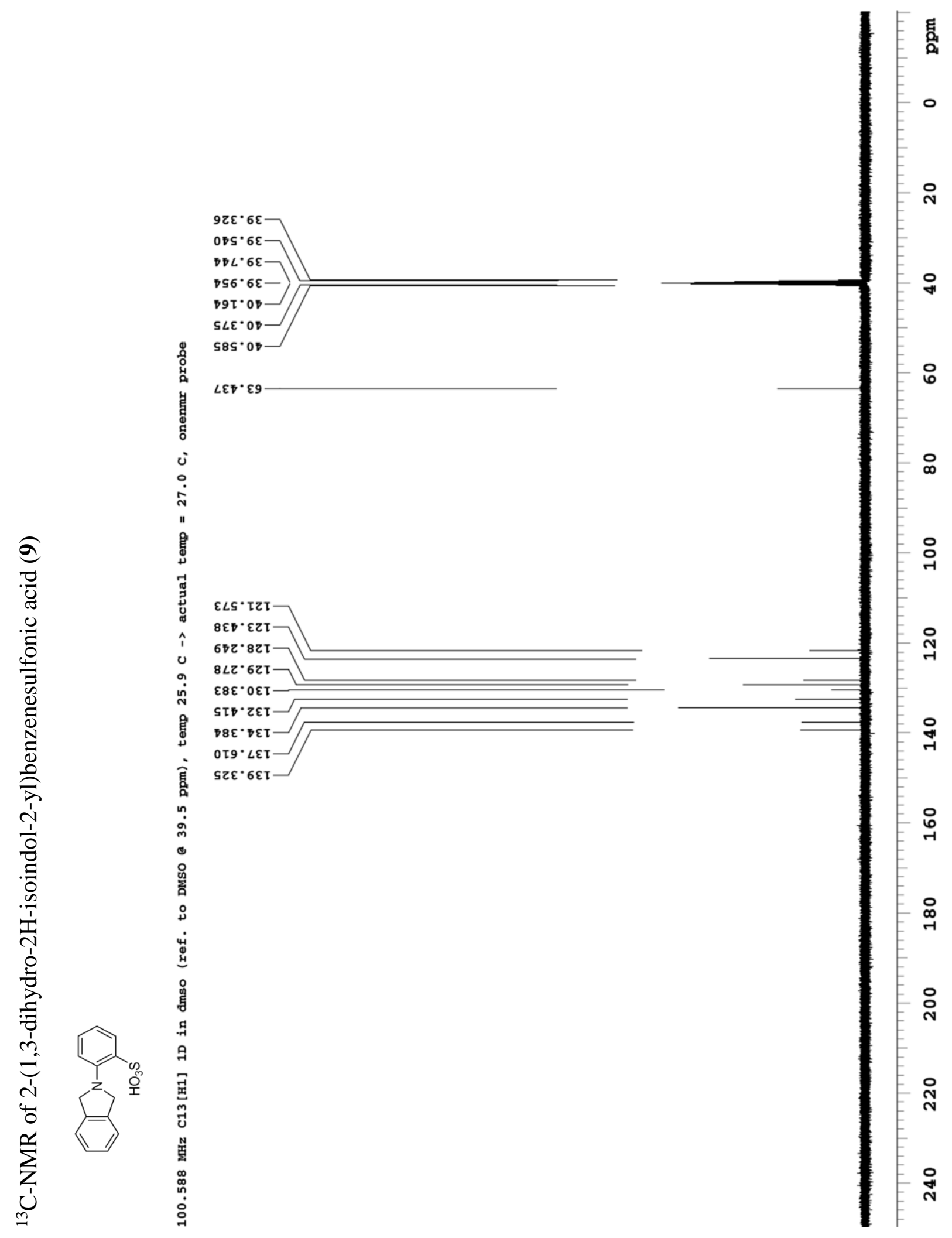


${ }^{1} \mathrm{H}-\mathrm{NMR}$ of 3,3'-bis(sulfonato)-4,4'-bis(bromoacetamido)azobenzene (11)<smiles>O=C(CBr)Nc1ccc(N=Nc2ccc(NC(=O)CBr)c(S(=O)(=O)O)c2)cc1[O-]</smiles>

399.985 $\mathrm{MHz} \mathrm{H1}$ 1D in d20 (ref. to external acetone o $2.225 \mathrm{ppm}$ ), temp $25.9 \mathrm{C}$-> actual temp $=27.0 \mathrm{C}$, onenmr probe
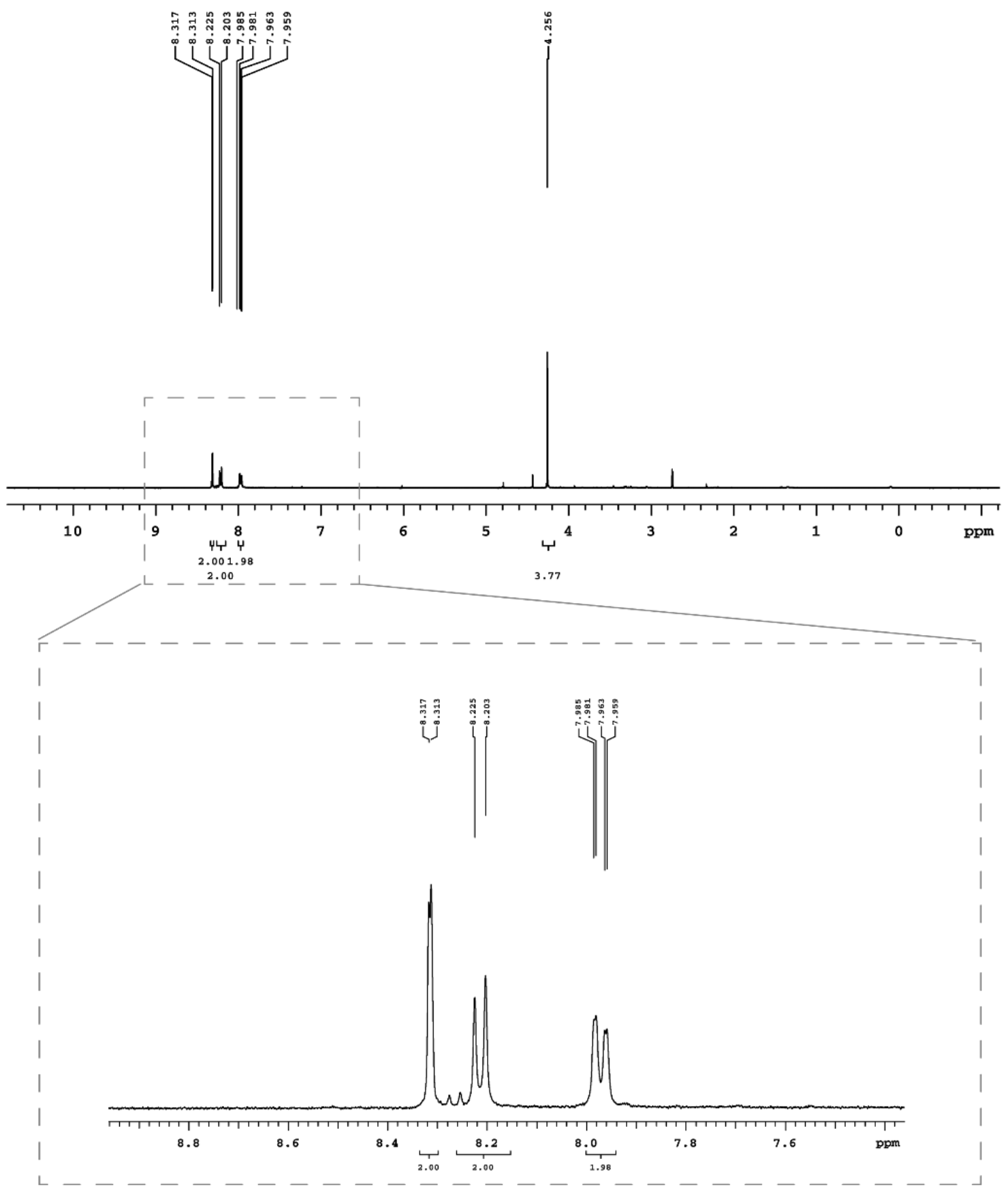

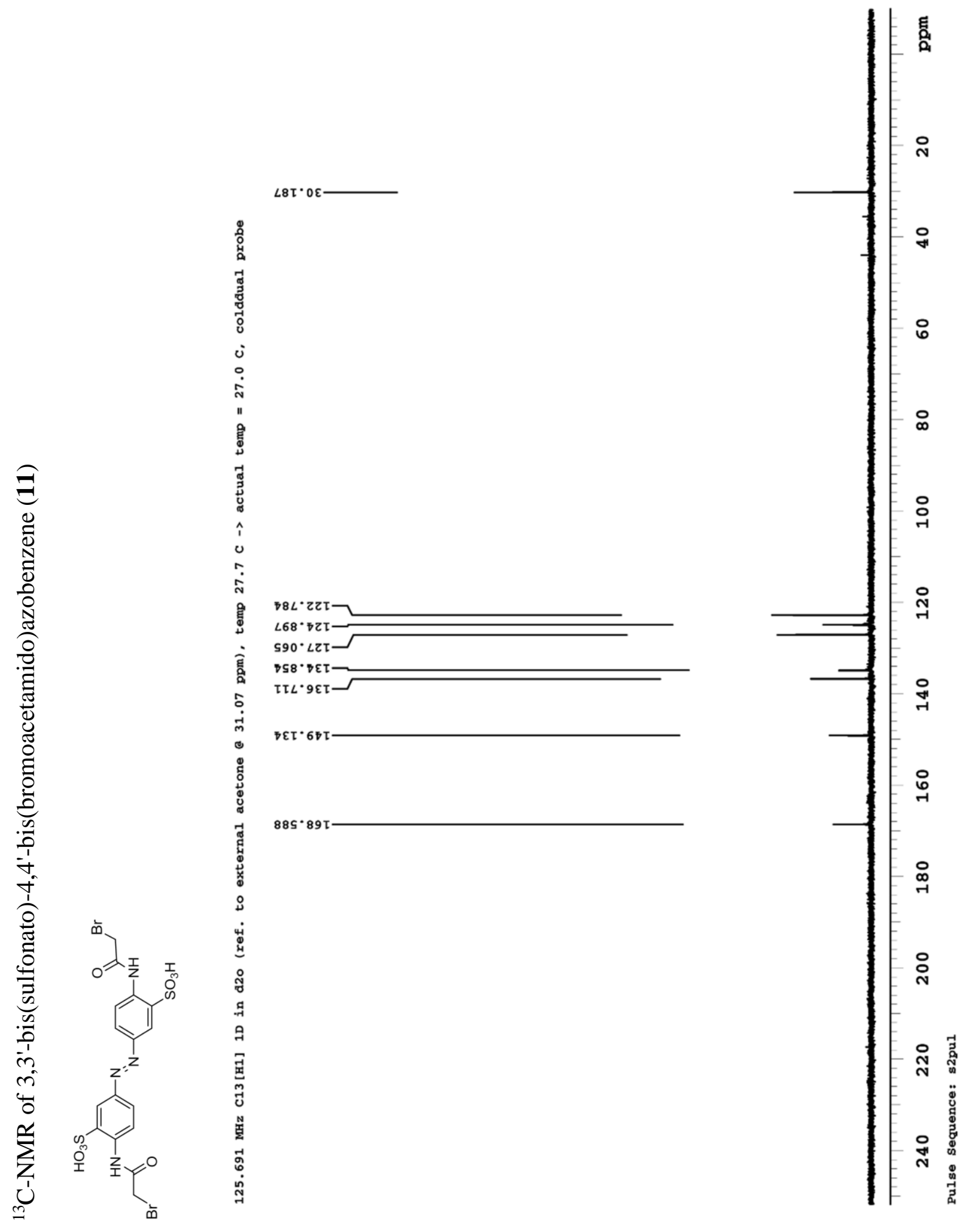
${ }^{1} \mathrm{H}-\mathrm{NMR}$ of 3,3'-bis(sulfonato)-4,4'-bis(azidoacetamido)azobenzene (12)<smiles>NCC(=O)Nc1ccc(NNc2ccc(NC(=O)CN)c(O)c2)cc1[O-]</smiles>

$399.986 \mathrm{MHz} H 1$ 1D in dmso (ref. to DMSO a $2.49 \mathrm{ppm}$ ), temp $25.9 \mathrm{C}$-> actual temp $=27.0 \mathrm{C}$, onenmr probe
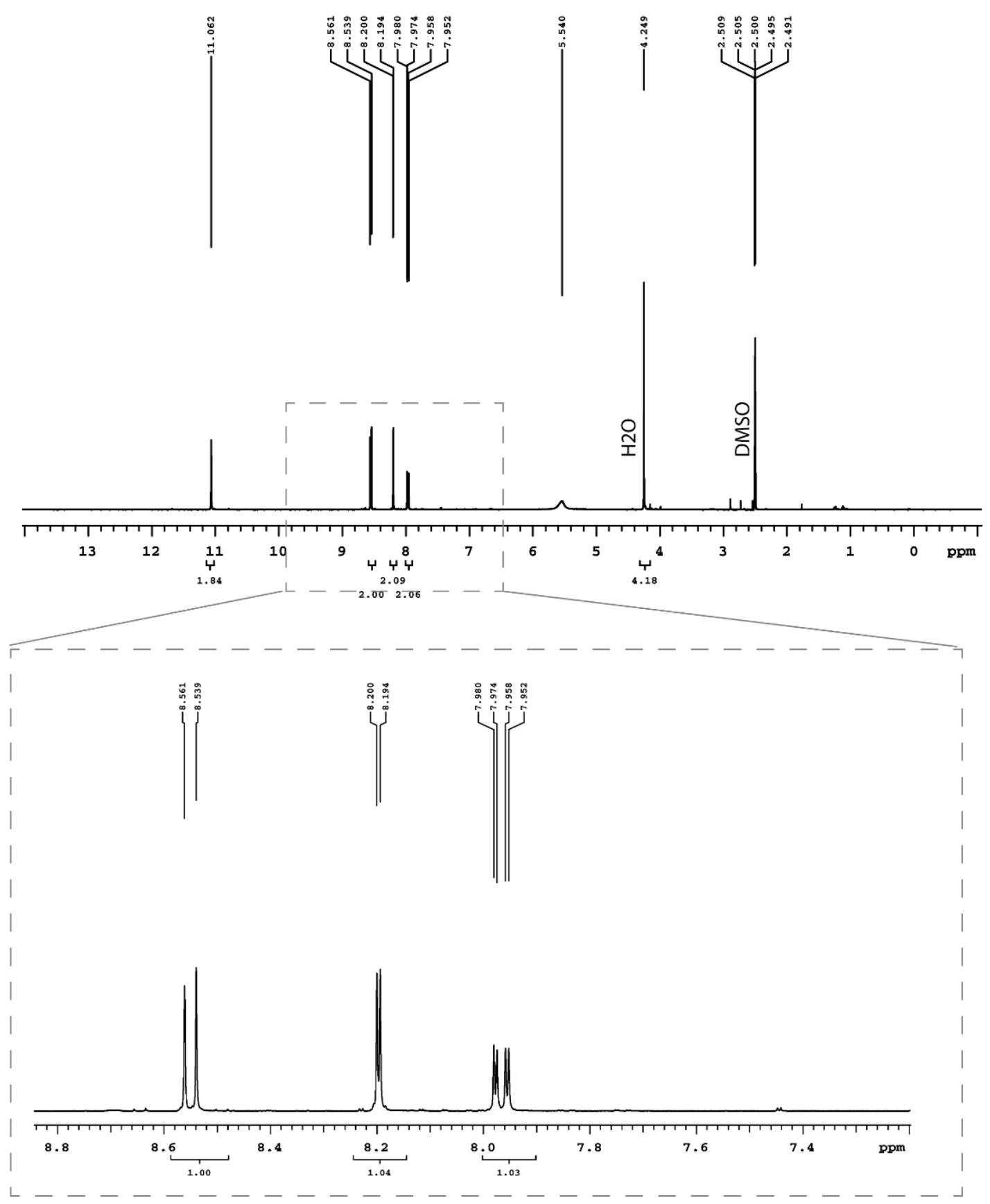


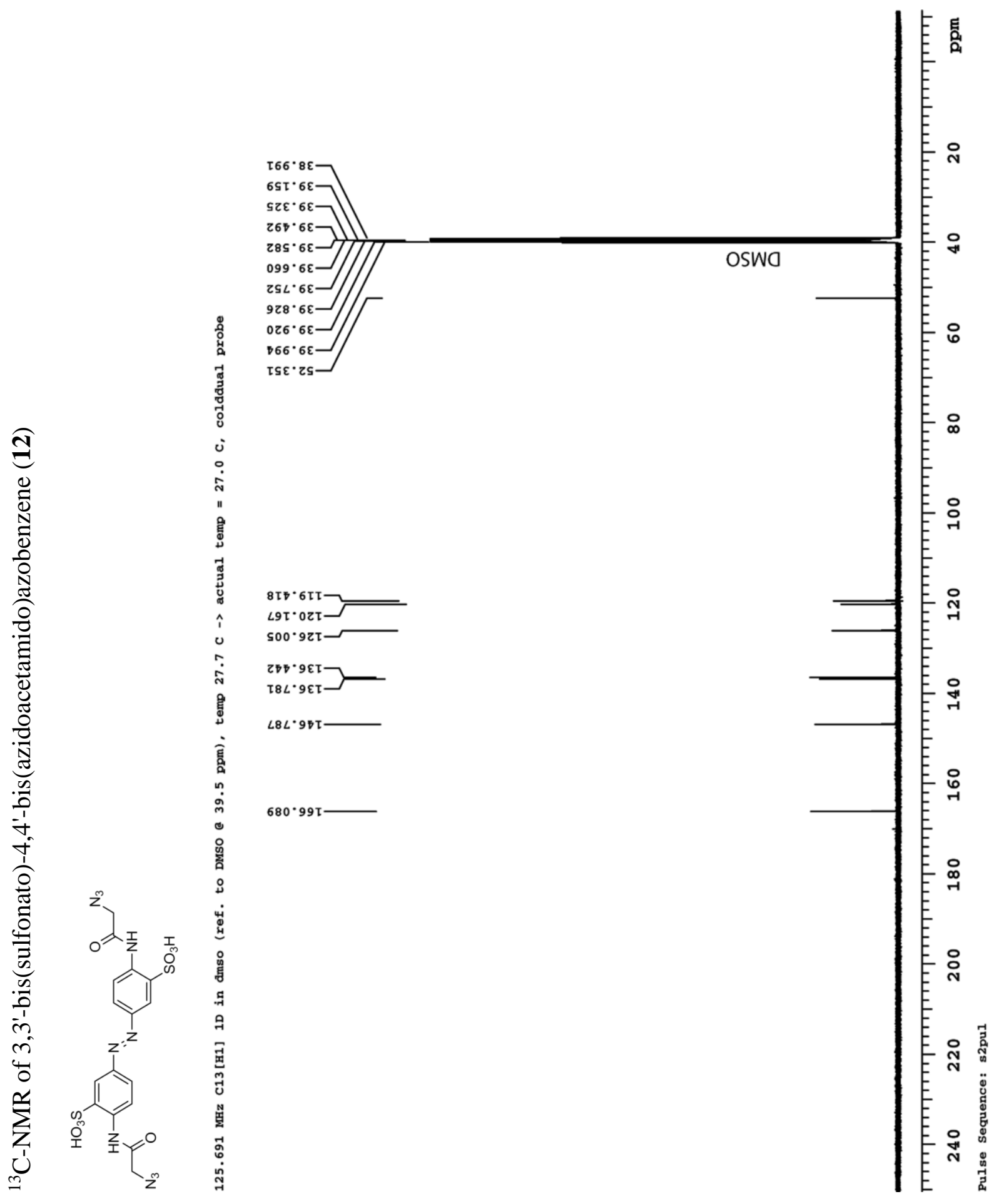


${ }^{1}$ H-NMR of 3,3'-bis(sulfonato)-4,4'-bis(prop-2-ynoylamido)azobenzene (13)<smiles>C#CC(=O)Nc1ccc(NNc2ccc(NC(=O)C#C)c(O)c2)cc1O</smiles>

$399.986 \mathrm{MHz}$ H1 $1 \mathrm{D}$ in amso (ref. to DMSO $2.49 \mathrm{ppm}$ ), temp $25.9 \mathrm{C}$-> actual termp $=27.0 \mathrm{C}$, onenmr probe

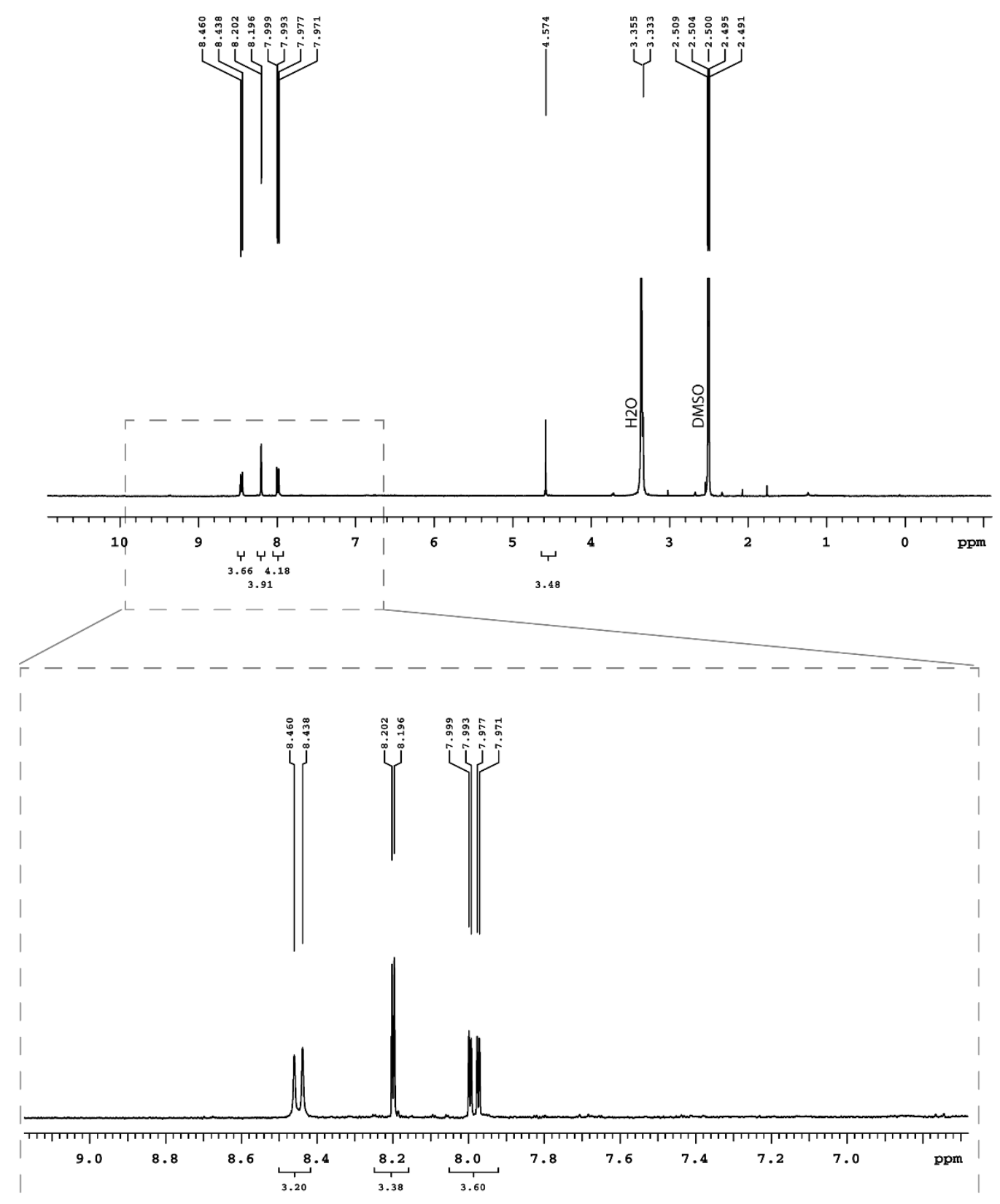



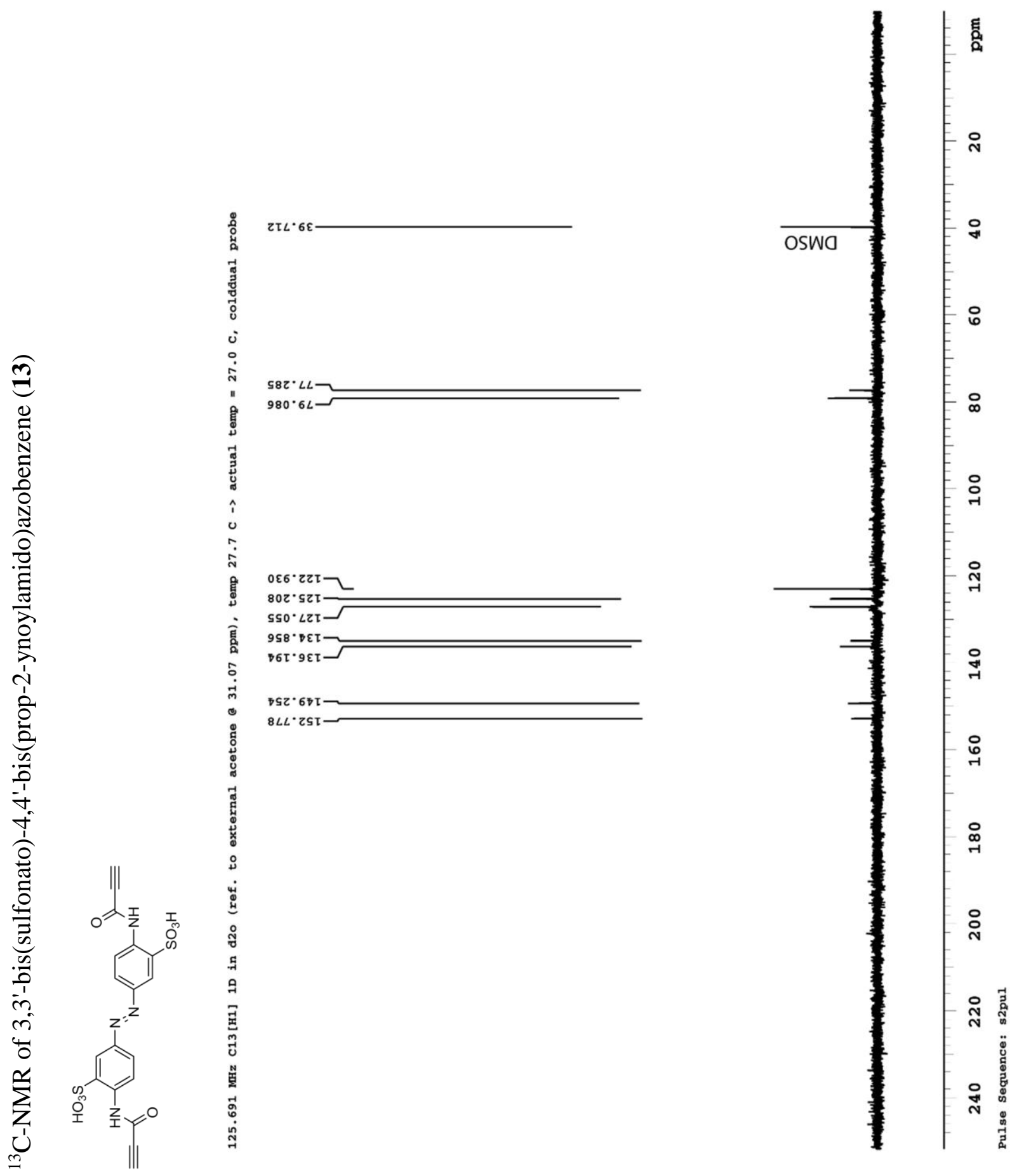
${ }^{1}$ H-NMR of 3,3'-bis(sulfonato)-4,4'-bis(buta-2,3-dienoylamido)azobenzene (14)
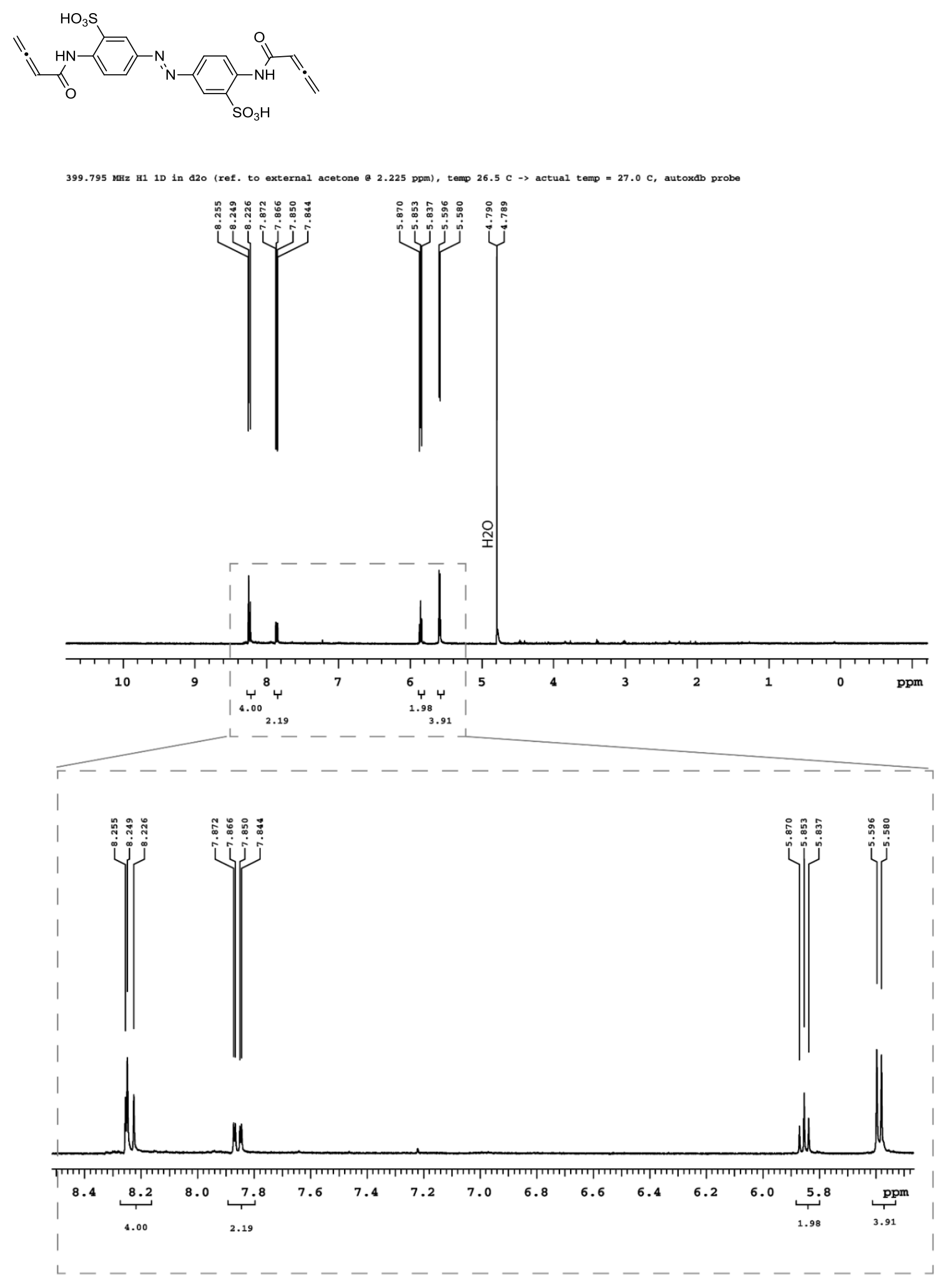

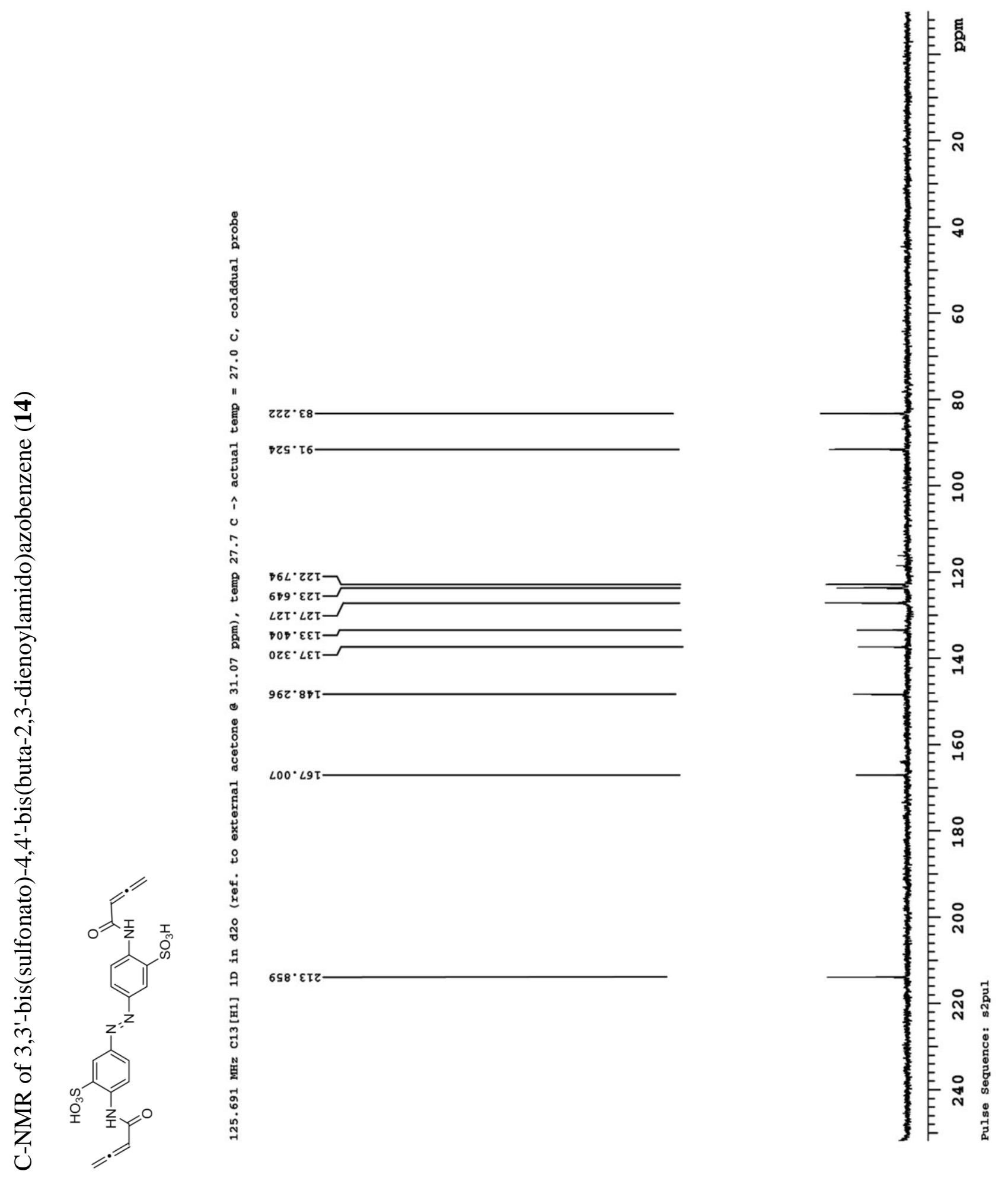


\section{References}

(1) Abbas, A., Xing, B., and Loh, T.-P. (2014) Allenamides as Orthogonal Handles for Selective Modification of Cysteine in Peptides and Proteins. Angew. Chem. Int. Ed. 53, 7491-7494.

(2) Shrimp, J. H., Hu, J., Dong, M., Wang, B. S., MacDonald, R., Jiang, H., Hao, Q., Yen, A., and Lin, H. (2014) Revealing CD38 Cellular Localization Using a Cell Permeable, Mechanism-Based Fluorescent Small-Molecule Probe. J. Am. Chem. Soc. 136, 56565663.

(3) Burns, D. C., Zhang, F., and Woolley, G. A. (2007) Synthesis of 3,3[prime]bis(sulfonato)-4,4[prime]-bis(chloroacetamido)azobenzene and cysteine cross-linking for photo-control of protein conformation and activity. Nat. Protoc. 2, 251-258.

(4) Zhang, Z., Burns, D. C., Kumita, J. R., Smart, O. S., and Woolley, G. A. (2003) A WaterSoluble Azobenzene Cross-Linker for Photocontrol of Peptide Conformation. Bioconjugate Chem. 14, 824-829.

(5) Jafari, M. R., Deng, L., Kitov, P. I., Ng, S., Matochko, W. L., Tjhung, K. F., Zeberoff, A., Elias, A., Klassen, J. S., and Derda, R. (2013) Discovery of Light-Responsive Ligands through Screening of a Light-Responsive Genetically Encoded Library. ACS Chem Biol 9, 443-450. 